\title{
Hydro-geochemical analysis and quality evaluation of surface water in the Mamu River basin, southeastern Nigeria
}

\author{
Chinero Nneka Ayogu ${ }^{1} \cdot$ Raphael Iweanya Maduka $^{2} \cdot$ Nnadozie Onyekachi Ayogu $^{2} \cdot$ Chioma N. Njoku $^{3} \cdot$ \\ Nkechi C. Chinedu-Asogwa ${ }^{4}$
}

Received: 12 September 2019 / Accepted: 1 June 2020 / Published online: 10 June 2020

(c) The Author(s) 2020

\begin{abstract}
Mamu basin is a major tributary of Anambra drainage basin and a reservoir for wastewater from agricultural and runoff processes within the basin. Water quality of the Mamu basin was evaluated to determine its suitability for potable water and agrarian uses. This study utilized 24 water samples collected during the rainy and dry season from the upstream and downstream segments of the sub basins within River Mamu. Hdyro-geochemical analytical results were employed in the evaluation of several water quality criteria such as QWI, SAR, TH, SSP, MAR, PI, KR, Na\% and \%E of the water from the basin. The results suggested that the surface water is unfit for ingestion when compared with the WHO and Standard Organization of Nigeria (SON) standards. However, the QWI result showed that $66.7 \%$ of the water samples are good for consumption in the rainy season, while $75 \%$ of the samples are classified unfit for drinking in the dry season. Parameters such as $\mathrm{Fe}^{2+}, \mathrm{Mn}^{2+}$, TDS, temperature and total coliform ( $p<0.001$ ) exhibited temporal variation unlike $\mathrm{pH}, \mathrm{EC}, \mathrm{Ce}, \mathrm{Ca}^{2+}, \mathrm{Mg}^{2+}, \mathrm{Cl}^{-}, \mathrm{K}+, \mathrm{NO}_{3}$, $\mathrm{PO}_{4}{ }^{3-}, \mathrm{Na}^{+}, \mathrm{HCO}_{3}{ }^{-}, \mathrm{Zn}^{2+}, \mathrm{TSS}, \mathrm{SO}_{4}, \mathrm{DO}, \mathrm{BOD}$ and turbidity which showed no response to season. Based on the results of SAR, TH, SSP, PI, KR, Na\% and US salinity plots, the surface water is suitable for irrigation. Conversely, the MAR and \%E results pointed out that water treatment is vital before use. The basin water is associated with permanent hardness due to $\mathrm{CaCl}_{2}$ coupled with the dominance of $\mathrm{Mg}^{2+}$ and $\mathrm{SO}_{4}{ }^{2-}$. Gibbs plots and Stiff diagram showed that geology and dissolution process have an influence on the water chemistry via weathering and rock-mineral interactions, while chemical ratios and correlation coefficients $\left(R^{2}\right)$ point on anthropogenic activities.
\end{abstract}

Keywords Mamu River basin $\cdot$ Hydro-geochemistry $\cdot$ QWI $\cdot$ Weathering $\cdot$ Host rocks and minerals $\cdot$ Anthropogenic

\section{Introduction}

\section{Background of study}

Freshwater is a limited resource. On a global scale, its percentage is $2.5 \%$ and less than $1 \%$ is exploited (UNEP 2008). Water is prominently sourced from rivers which support a lot

Chinero Nneka Ayogu

chinero.ayogu@unn.edu.ng

1 Department of Geography, University of Nigeria, Nsukka, Nigeria

2 Department of Geology, University of Nigeria, Nsukka, Nigeria

3 Department of Mass Communication, University of Nigeria, Nsukka, Nigeria

4 Department of Mass Communication, Covenant University, Ogun State, Ota, Nigeria of livelihood for mankind. For instance, Mamu is a tributary of Anambra basin which supports formidable bio geographic zone composed of different wildlife species (Phil-Eze 2001), a host to different fish species-Clarrids, Gymnarchus and Mormyrids, and about 52 species originating from two families-Characidea and Mochokidae (Awachie and Walson 1978). This suggests that the sanity of drainage basins should not be compromised.

Often times, compromise in quality of water emanates from discharge of effluent, nature of host rock, agricultural practices, dumping of wastes indiscriminately, etc. (Nzeadibe and Ajaero 2011; Okogbue et al. 2012; Dinka et al. 2015). Indeed, there is no need gainsaying that monitoring the quality of waters in the drainage basin should not be given premium position. Such actions and activities have inadvertently increased the problems of freshwater supply which if unchecked will result in server scarcity and overexploitation (Okogbue et al. 2012). It was reported that 
over 70 million people suffer from hunger globally (Diagi 2018). Some of the main causes of this have been ascribed to famine orchestrated by drought which is directly linked to decreasing rainfall and increasing population. Ishaka et al. (2011) noted that about $16 \%$ (about 1.2 billion) of the world's population do not have access to improved water supply, while $70 \%$ of such people live in rural areas and rely on agriculture for their daily living (Odetola and Etumnu 2013). In rural Africa, only $45 \%$ of the populace has access to improved water supply and more than 237 million people depend on surface waters for their survival. In the urban centers, 37 million people (83\%) have access to quality water (UNICEF and WHO 2009).

In Nigeria, statistics have shown that about $36 \%$ of urban dwellers and $58 \%$ of rural dwellers have no access to safe water (Eneh 2007; Lohdip and Gongden 2013). However, Ishaku et al. (2011) asserted that the percentage of rural communities without access to improved water supply have increased to $70 \%$. This implies that $70 \%$ of the communities resort to hand-dug wells, springs, canals, lakes and rivers for their daily water needs (Lohdip and Gongden 2013), and this has led to severe death due to cholera outbreak in Nigeria. Recently, about 4665 cholera cases and 350 deaths were recorded (Ishaku et al. 2011). UNICEF and WHO (2009) avowed that approximately $80 \%$ of the health challenges which claimed the lives of over 1.8 million children annually in developing nation is traceable to poor water and sanitation. Thus, the importance of potable water in the survival of sub-Sahara Africans should not be trifled with.

Nigeria's population is at about 168.83 million in 2012 (UNDESA 2012), and over 70\% of its population live in abject poverty (Odetola and Etumnu 2013). The percentages of the poor in the rural and urban centers are $63.27 \%$ and 43.19\%, respectively (Etim and Udoh 2013). The nation's human development index (HDI) value for 2018 is 0.534 , with the country ranking 158 out of 189 countries. Thus, Nigeria was classified among the low human development category (UNDP 2013). According to United Nations (2009), 51.7\% and 48.3\% of Nigeria's population dwell in rural and urban centers, respectively, with a population density of 167.5 people per $\mathrm{km}^{2}$ (Pavelic et al. 2012). The main source of employment in Nigeria is agriculture. It provides a means of livelihood for about $70 \%$ of the masses and contributes $40 \%$ to gross domestic product (GDP) (Pavelic et al. 2012; Odetola and Etumnu 2013). Against the above background, beside the need for potable water, monitoring water is vital in irrigation scheme. This is because irrigation water contains dissolved solutes and industrial effluents which hinders crop yield and depreciates soil fertility. Dissolved solutes act directly as toxins to plants; alter nutrients available to plants; and impact negatively on their growth. It also causes subcellular harm and remarkable vulnerability to diseases and parasitic invasion (Boah et al. 2015; Laze et al. 2016).

Surface water resource potential of Nigeria is estimated at 267.3 billion cubic meters (FGN, 2004). About $10,812,400$ hectares, constituting $11.5 \%$ of Nigeria's estimated $94,185,000$ hectare surface area, is covered by major rivers (Lohdip and Gongden 2013). Previously, the irrigation potential of Nigeria was between 1.5 and 3.2 million ha, but presently, it is about 2.1 million ha. About $76.2 \%$ of the land area is irrigated from surface drainage (FAO 2005). Importantly, Nigeria accounts for $35.2 \%$ of the total population of the world's small ruminants (Pavelic et al. 2012). Therefore, the need for optimum utilization of the nation's water resources to maintain its water and food security cannot be gainsaid.

Importantly, $70 \%$ of agricultural water demand in Nigeria is serviced by $5 \%$ of the estimated $250 \mathrm{~km}^{3}$ total surface run-off emanating from the annual total rainfall of $560 \mathrm{~km}^{3}$ and Mamu basin receives $66 \times 10^{9} \mathrm{~m}^{3}$ (Pavelic et al. 2012; Lohdip and Gongden 2013). Following the rainfall amount of the study area over the last 5 decades, Fig. 1 indicates that the basin experiences high tropical rainfalls though, with a slight decline. Surprisingly, there is no dam in the study area to facilitate the harnessing of the basin full potential. Thus, Nigeria is gradually becoming a water-scare nation where the nation's water resources are continuously being subjected under pressure due to population surge and erratic weather conditions. The population reference Bureau (prB) (2000) asserted that the nation would be one of the 48 countries expected to face shortage of water. Water availability per capita is expected to drop to $1175 \mathrm{~m}^{3}$, while population would rise as high as 238.4 million people in year 2025. This report underscores the need for proper drainage management. Mamu River, a tributary of Anambra drainage basin, is supporting a lot of agricultural activities and other allied ventures. Unfortunately, its hydro-geochemical status has not been documented. Central in this paper is an investigationcum-evaluation of the surface water quality of Mamu River

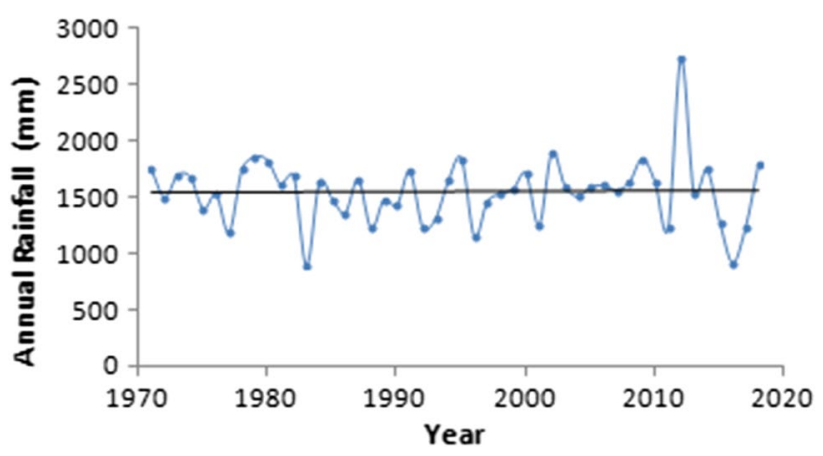

Fig. 1 Annual rainfall of the basin 
basin to check its appropriateness for domestic and agricultural use.

\section{Materials and methods}

\section{Study area overview}

The study area is Mamu basin bounded within latitude $6^{\circ}$ $00^{\prime}$ and $7^{\circ} 30^{\prime} \mathrm{N}$ and longitude $7^{\circ} 00^{\prime}$ and $7^{\circ} 30^{\prime} \mathrm{E}$ (Fig. 2). Mamu basin is situated within the Anambra Basin of the Benue Trough with a stratigraphy that supports successive geological evolution of the southeastern Nigeria (Table 1). According to Shell (1957), Kogbe (1981) and Nfor (2003), Mamu River lies within a sedimentary basin underlain by Quaternary (alluvial plain and coastal plain sands) and Tertiary rocks-cum-Cretaceous sedimentary sequences-Imo, Ajalli and Mamu, Nsukka Formations together with Nkporo and Awgu Shale (Fig. 3).
Table 1 Stratigraphy of the Anambra basin (Nfor 2003)

\begin{tabular}{|c|c|}
\hline Age & Stratigraphic unit \\
\hline Eocene & $\begin{array}{l}\text { Ameki Group (including Nanka Sands, Nsugbe } \\
\text { Formation) }\end{array}$ \\
\hline Paleocene & Imo Shale \\
\hline Maastrichtian & Nsukka formation, Ajali Sandstone, Mamu formation \\
\hline Campanian & $\begin{array}{l}\text { Nkporo Group (including Nkporo Shale, Owelli } \\
\text { Sandstone, Enugu Shale, Afikpo Sandstone, Otobi } \\
\text { Sandstone) }\end{array}$ \\
\hline Santonian & Non-deposition \\
\hline Coniacian & $\begin{array}{l}\text { Awgu Group (including Awgu Shale, Agbani Sand- } \\
\text { stone) }\end{array}$ \\
\hline Turonian & Ezeaku formation (including Amasiri Sandstone) \\
\hline Cenomanian & Odukpani Formation \\
\hline Albian & Asu River Group \\
\hline Precambrian & Basement Complex \\
\hline
\end{tabular}

Fig. 2 Mamu River basin map

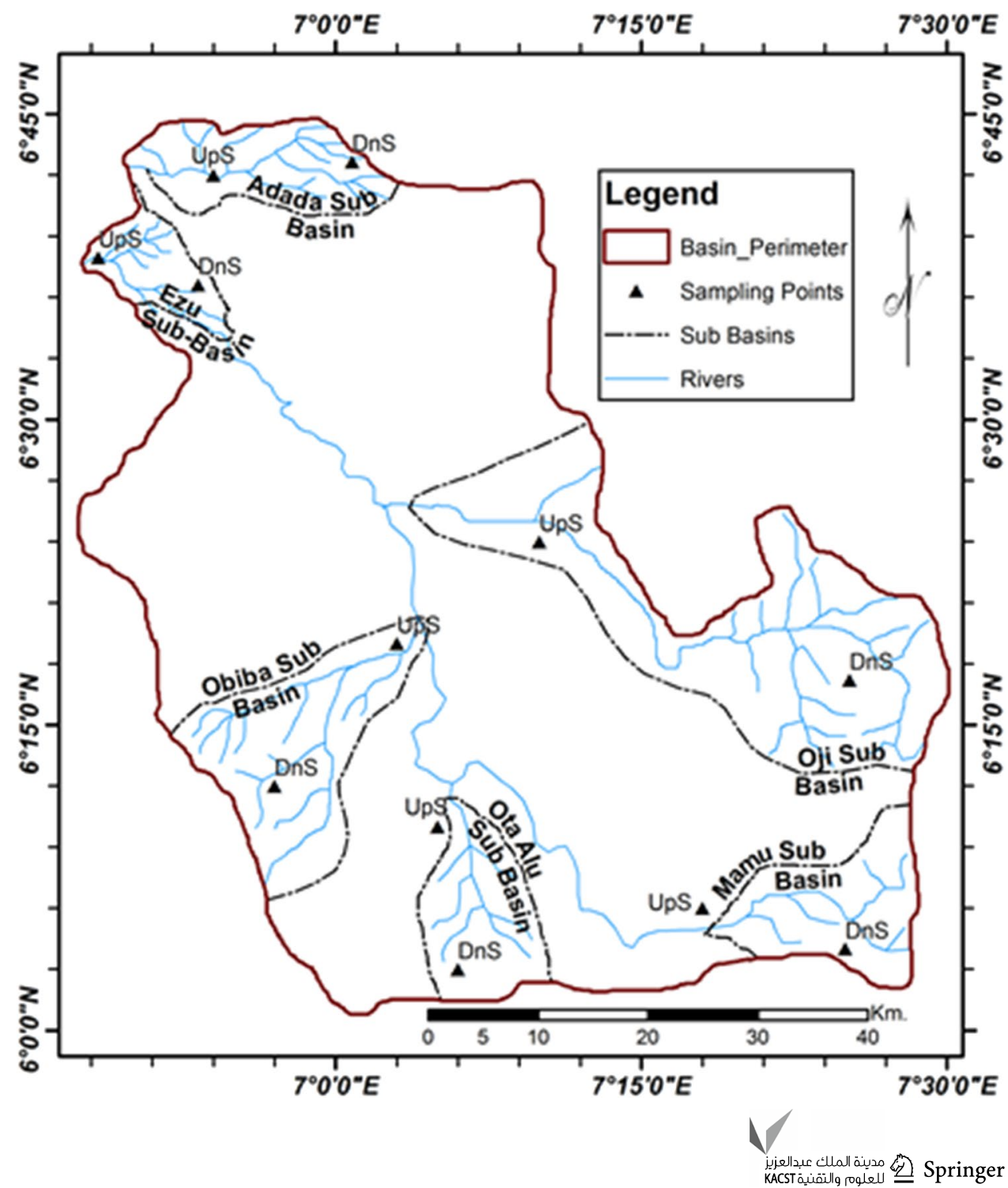


Fig. 3 Mamu basin drainage pattern

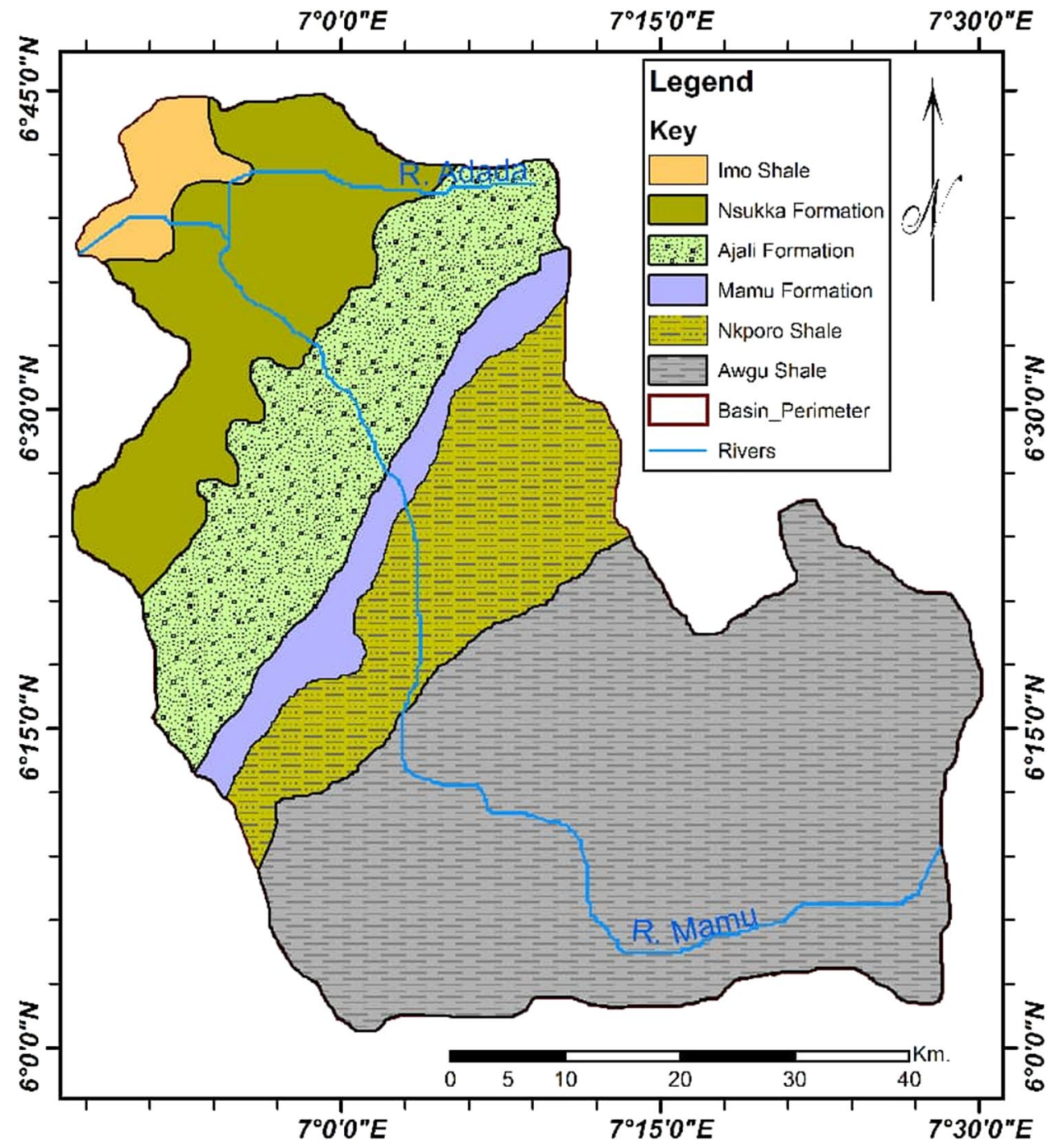

Mamu basin falls within the tropical rainy climate (Af). The mean annual rainfall ranges between 1750 and $2050 \mathrm{~mm}$. It experiences seven months of effective rainfall from April to October and five months of dry seasonNovember to March. The mean maximum temperature is $30.6{ }^{\circ} \mathrm{C}$ and the minimum temperature is $20.0{ }^{\circ} \mathrm{C}$ (Okogbue et al. 2012) with annual average temperature of $27-28^{\circ} \mathrm{C}$ (Monanu and Inyang 1975). In the basin, relative humidity and pressure range from 60 to $80 \%$ and between 1010 to 1012.9 mbar (Monanu and Inyang 1975). Mamu River has many tributaries with a drainage pattern that is considered to be dendritic (Figs. 2,4), underscoring the uniformity of the underlying lithology-mostly shale, which support tall trees and bushes descriptive of a rain forest.

\section{Sampling and analysis}

Field work commenced after examining base map, literature review and reconnaissance survey. Twenty-four (24) water samples were collected from the sub basins-Adada, Oji, Ota-Alu, Obibia, Ezu and Mamu main channel at the upstream and downstream segment during dry and rainy seasons in December 2009 and June 2010, respectively. Water sample locations were tracked with a hand-held GPS device. Determination of physical parameters was done in situ using standard field equipment (Table 2).

The water samples were collected using 60-cl clean acid-sterilized plastic bottles following custody of practice and were taken to the laboratory at National Steel Raw Materials Exploration Agency, Kaduna, Nigeria. Samples were analyzed for physiochemical and biological parameters in the laboratory following standard test methods outlined by APHA (1995) and UNESCO/WHO/UNEP (1996) as shown in Table 2. The water samples' physiochemical parameters were determined using the atomic absorption spectrometer (AAS) - model SOLAAR 969AA Unican Series with suitable hollow cathode lamp, by means of its 
Fig. 4 The geology of the Anambra River Basin

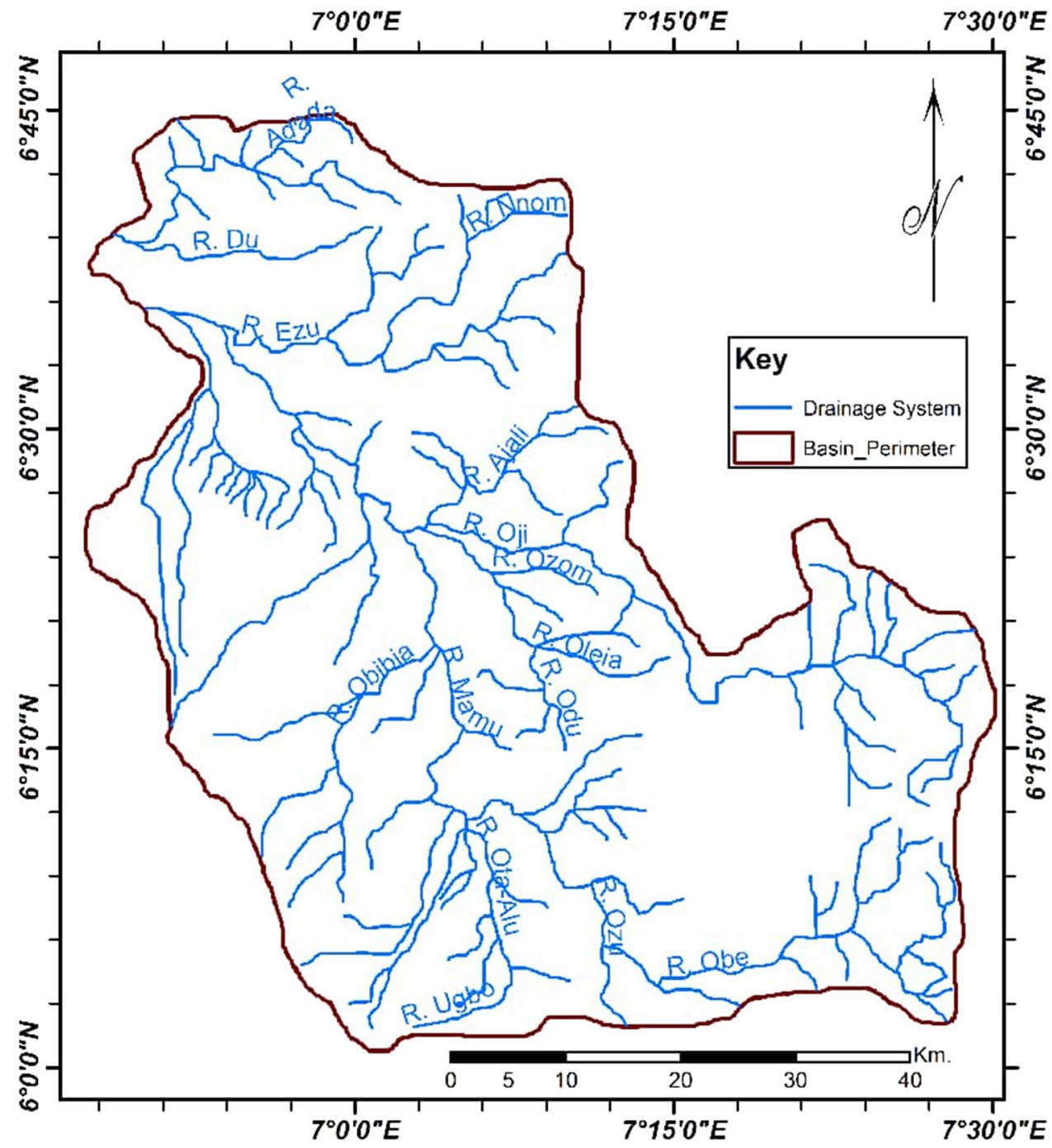

set of standard series order: $-0,2,4,6,8$ and 10 , respectively, to achieve the calibration curve.

\section{Data analysis}

All water chemical indices were derived from the measured water quality parameters. Except for water quality index (WQI), other formula adopted for the calculation of water quality is summarized in Table 3.

There are various methods of determining drinking water quality, but to establish the suitability of Mamu basin water for drinking, Weighted Arithmetic Water Quality Index Method (WAWQI) was used to generate WQI. In this study, 17 selected water quality parameters were analyzed. The WQI computation requires the analyzed, standard and permissible values of ions present in water (Nag and Das 2014). Equation 1 is the metrical expression of WQI computation,
$\mathrm{WQI}=\sum q_{n} W_{n} / \sum W_{n}$

where $q_{n}$ is quality rating of nth water quality parameter, $W_{n}$ is unit weight of nth water quality parameter, while quality rating $\left(q_{n}\right)$ is evaluated using Eq. 2:

$q_{n}=\left[\left(V_{n}-V_{\text {id }}\right) /\left(S_{n}-V_{\text {id }}\right)\right] \times 100$

where $V_{n}$ is the estimated value of nth water quality parameter at a given sample location, $V_{\text {id }}$ connotes ideal value for nth parameter in pure water and $S_{n}$ is standard permissible value of nth water quality parameter.

It is important to note that, apart from $\mathrm{pH}$ and $\mathrm{DO}$ which have ideal values of 7 and $14.6 \mathrm{mg} / \mathrm{l}$, respectively, all other parameters are 0 (Boah et al. 2015). The standard values of water quality parameters and their corresponding ideal values and generated unit weights are presented in Table 4

The unit weight $\left(W_{n}\right)$ is calculated using Eq. 3, 
Table 2 Water quality analysis adopted methods
Table 3 Evaluated water quality parameters' estimation methods

\begin{tabular}{|c|c|c|}
\hline Parameter & Symbol & Method of analysis \\
\hline $\mathrm{pH}$ & $\mathrm{pH}$ & In situ using Hanna HI9813 Grochek meter \\
\hline Electrical conductivity & $\mathrm{EC}$ & In situ using Hanna HI9813 Grochek meter \\
\hline Carbon & $\mathrm{C}$ & Loss of ignition \\
\hline Calcium & $\mathrm{Ca}^{2+}$ & $\operatorname{EDTA}^{\mathrm{b}}(0.05 \mathrm{~N})$ titrimetric \\
\hline Magnesium & $\mathrm{Mg}^{2+}$ & $\operatorname{EDTA}^{\mathrm{b}}(0.05 \mathrm{~N})$ titrimetric \\
\hline Chloride & $\mathrm{Cl}^{-}$ & Titration using $0.05 \mathrm{~N} \mathrm{AgNO}_{3}$ \\
\hline Potassium & $\mathrm{K}^{+}$ & Flame photometric \\
\hline Nitrate & $\mathrm{NO}_{3}$ & Spectrophotometric \\
\hline Phosphate & $\mathrm{PO}_{4}^{3-}$ & Spectrophotometric \\
\hline Sodium & $\mathrm{Na}^{+}$ & Flame photometric \\
\hline Bicarbonate & $\mathrm{HCO}_{3}^{-}$ & Spectrophotometer \\
\hline Zinc & $\mathrm{Zn}^{2+}$ & Atomic absorption spectrometer (AAS) \\
\hline Iron & $\mathrm{Fe}^{2+}$ & Atomic absorption spectrometer (AAS) \\
\hline Manganese & $\mathrm{Mn}^{2+}$ & Atomic absorption spectrometer (AAS) \\
\hline Total dissolved solids & TDS & In situ using Hanna HI9813 Grochek meter \\
\hline Total suspended solids & TSS & In situ using Whatman meter \\
\hline Temperature & Temp & Thermometer \\
\hline Sulfate & $\mathrm{SO}_{4}$ & Spectrophotometric \\
\hline Dissolved oxygen & DO & In situ using Oxi 330i oxygen meter \\
\hline Biochemical oxygen demand & BOD & Manometric \\
\hline Turbidity & Turb & Turbidimeter \\
\hline Total coliform & $\mathrm{TC}$ & Filter membrane method \\
\hline
\end{tabular}

\begin{tabular}{|c|c|c|c|}
\hline Quality parameter & Symbol & Formula adopted & Source reference \\
\hline Sodium percentage & $\mathrm{Na} \%$ & $\% \mathrm{Na}=\frac{\mathrm{Na}^{+}+\mathrm{K}^{+}}{\mathrm{Na}^{+}+\mathrm{K}^{+}+\mathrm{C}^{2+}+\mathrm{Mg}^{2+}} \times 100$ & Khodapanah et al. (2009) ${ }^{\mathrm{a}}$ \\
\hline Total hardness & $\mathrm{TH}$ & $\mathrm{TH}=\left(\mathrm{Ca}^{2+}+\mathrm{Mg}^{2+}\right) \times 50$ & Ragunath $(1987)^{\mathrm{a}}$ \\
\hline Magnesium ratio & MAR & $\mathrm{MAR}=\frac{\mathrm{Mg}^{2+}}{\mathrm{Ca}^{2+}+\mathrm{Mg}^{2+}} \times 100$ & Paliwal (1972) $)^{\mathrm{a}}$ \\
\hline Soluble sodium percent (SSP) & SSP & $\mathrm{SSP}=\frac{\mathrm{Na}^{+} \times 100}{\mathrm{Ca}^{2+}+\mathrm{Mg}^{2+}+\mathrm{Na}^{+}}$ & Shah and Mistry $(2013)^{\mathrm{b}}$ \\
\hline Kelley's ratio & KR & $\mathrm{KR}=\frac{\left(\mathrm{Na}^{+}\right)^{2}}{\mathrm{Ca}^{2+}+\mathrm{Mg}^{2+}}$ & $(\text { Kelly } 1963)^{\mathrm{c}}$ \\
\hline$\%$ Balance error & $\% \mathrm{E}$ & $\% E=\frac{\sum \text { Cations }-\sum \text { Anions }}{\sum \text { Cations }+\sum \text { Anions }}$ & Fetter $(2000)^{a}$ \\
\hline Sodium adsorption ratio & SAR & $\mathrm{SAR}=\frac{\mathrm{Na}^{+}}{\sqrt{\mathrm{Ca}^{2+}+\mathrm{Mg}^{2+} / 2}}$ & $\operatorname{USSL}(1954)^{\mathrm{a}}$ \\
\hline Permeability index & PI & $\mathrm{PI}=\frac{\mathrm{Na}^{+}+\sqrt{\mathrm{HCO}_{3}^{-}}}{\mathrm{Ca}^{2+}+\mathrm{Mg}^{2+}} \times 100$ & Doneen $(1964)^{\mathrm{a}}$ \\
\hline
\end{tabular}

Source: ${ }^{\mathrm{a} D i n k a}$ et al. (2015); ${ }^{\mathrm{b}}$ Shah and Mistry (2013); ${ }^{\mathrm{c}} \mathrm{Nag}$ and Das (2014)

All the ionic concentrations are in $\mathrm{mg} / \mathrm{l}$

$W_{n}=K / S_{n}$

where $S_{n}$ is the standard permissible value of nth water quality parameter, $k$ is the constant of proportionality and it is calculated by the expression given in Eq. 4,

$K=\left[1 /\left(\sum 1 / S_{n=1,2, \ldots n}\right)\right]$.
Base maps of the study area were produced using Arc GIS 9 (version 9.3), while Aqua-Chem was used for graphical presentations of physicochemical data to identify hydro-geochemical facie. Graphical explanation of the result was done with United States Salinity Laboratory (1954) and Wilcox (1955) plots. 
Table 4 Standard values of water quality parameters and their corresponding ideal values and generated unit weight

\begin{tabular}{lllll}
\hline Parameter $^{\mathrm{a}}$ & $\mathrm{Sn}^{\mathrm{b}}(\mathrm{WHO} 2007)$ & $\begin{array}{l}\text { Ideal value } \\
(\text { Vid })\end{array}$ & $\begin{array}{l}\text { Constant of propor- } \\
\text { tionality }(\mathrm{k})\end{array}$ & Unit weight (Wn) \\
\hline $\mathrm{pH}$ & $6.5-8.5(7.5)^{\mathrm{c}}$ & 7 & 0.141086 & 0.018811 \\
$\mathrm{Ca}^{2+}$ & 75 & 0 & 0.141086 & 0.001885 \\
$\mathrm{Mg}^{2+}$ & 30 & 0 & 0.141086 & 0.004713 \\
$\mathrm{Cl}^{-}$ & 250 & 0 & 0.141086 & 0.000566 \\
$\mathrm{~K}^{+}$ & 10 & 0 & 0.141086 & 0.014139 \\
$\mathrm{NO}_{3}$ & 45 & 0 & 0.141086 & 0.003142 \\
$\mathrm{Na}^{+}$ & 200 & 0 & 0.141086 & 0.000707 \\
$\mathrm{HCO}_{3}^{-}$ & 500 & 0 & 0.141086 & 0.000283 \\
$\mathrm{Zn}^{2+}$ & 3 & 0 & 0.141086 & 0.047128 \\
$\mathrm{Fe}^{2+}$ & 0.3 & 0 & 0.141086 & 0.471283 \\
$\mathrm{Mn}{ }^{2+}$ & 0.4 & 0 & 0.141086 & 0.353463 \\
$\mathrm{TDS}^{-4}$ & 500 & 0 & 0.141086 & 0.000283 \\
$\mathrm{TSS}^{-4}$ & 500 & 0 & 0.141086 & 0.000283 \\
$\mathrm{SO}_{4}$ & 250 & 0 & 0.141086 & 0.000566 \\
$\mathrm{DO}$ & 5 & 14.6 & 0.141086 & 0.028277 \\
$\mathrm{BOD}$ & 5 & 0 & 0.141086 & 0.028277 \\
Turbidity(FTU) & 5 & 0 & 0.141086 & 0.028277 \\
\hline
\end{tabular}

${ }^{a}$ Except order wise stated, all parameters are measured in $\mathrm{mg} / \mathrm{l}$

${ }^{\mathrm{b}}$ Standard permissible value for $n$th parameter

${ }^{\mathrm{c}}$ Mean

\section{Hypotheses}

The following hypotheses will guide the conduct of this research.

Null hypothesis ( $\mathrm{Ho}$ ) There is no significant difference between the concentration level of analyzed parameters of the water samples in the rainy and dry seasons.

Alternative hypothesis (HI) There is a significant difference between the concentration level of analyzed parameters of the water samples in the rainy and dry seasons.

\section{Results}

\section{Physical water parameters}

Tables 5 and 6 present the hydrochemical composition Mamu basin in the rainy and dry seasons, respectively, while Table 7 is the statistical results of water quality parameters. Temperature ranges between 23.30 and $26.90{ }^{\circ} \mathrm{C}$ and 24.20 and $27.0{ }^{\circ} \mathrm{C}$ in the rainy and dry seasons, respectively. The $\mathrm{pH}$ ranges from 5.6 to 6.8 in the rainy season and 5.1 to 6.9 in the dry season, indicating that the basin's water is moderately to slightly acidic. The close values in $\mathrm{pH}$ between seasons suggest an almost equal dissolution of $\mathrm{CO}_{2}$ in both seasons (Nganje et al. 2015). The high load of dissolved organic carbon $(10-115 \mathrm{mg} / \mathrm{l})$ in both seasons (Tables 5 and 6 ) is traceable to discharge of organic additives and industrial wastes into the basin (Urbaniak and Pietrzak 2011; Evans et al. 2005).

Increased acidity in dry season was attributed to dissolution of carbon dioxide and organic acids orchestrating from the decomposition of plants and animal remains over time since Mamu basin supports intensive agricultural activities coupled with its location in the humid tropical rain forest.

EC recorded $32.53 \mu \mathrm{scm}^{-1}$ as average value in the rainy season, while in the dry season, it was $35.68 \mu \mathrm{scm}^{-1}$ (Table 7). TDS ranges between 102 and $762 \mathrm{~mm} / \mathrm{l}$ and 95 and $800 \mathrm{mg} / \mathrm{l}$ for rainy and dry seasons, respectively (Tables 5 , 6). Dinka et al. (2015) noted that TDS values $>500 \mathrm{mg} / \mathrm{l}$ entail elevated salt concentration and water hardness. Total suspended solids and turbidity range were between 2.80 and $520 \mathrm{mg} / \mathrm{l}$ and 3.57 and $22.7 \mathrm{FTU}$ in the rainy season. In the dry season, TSS and turbidity spanned from 22 to $720 \mathrm{mg} / \mathrm{l}$ and 2.50 to $38.80 \mathrm{FTU}$, respectively (Tables 5, 6, 7). Such values were adjudged to be moderately high.

\section{Cations and anions distribution}

Soluble cations- $\mathrm{Na}^{+}, \mathrm{K}^{+}, \mathrm{Ca}^{2+}$ and $\mathrm{Mg}^{2+}$, were averagely $0.55,1.37,21.33$ and $157.75 \mathrm{mg} / \mathrm{l}$ in the rainy season and $0.62,2.11,24.82$ and $141.68 \mathrm{mg} / \mathrm{l}$, respectively, in the dry season (Table 7).

Sulfate and chloride are the dominant soluble anions in the basin's water as shown in Tables 5, 6, 7 and Fig. 5. Occurrence of chlorides is traceable to salts- $\mathrm{NaCl}$,

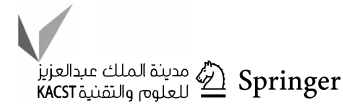


Table 5 Hydrochemistry of surface water from Mamu River basin in the rainy season

\begin{tabular}{|c|c|c|c|c|c|c|c|c|c|c|c|c|c|c|}
\hline \multirow[t]{3}{*}{ Parameter $^{\mathrm{a}}$} & \multicolumn{12}{|c|}{ Rivers $^{\mathrm{b}}$} & \multirow[t]{3}{*}{ WHO $(2007)^{\mathrm{c}}$} & \multirow[t]{3}{*}{ SON $(2007)^{c}$} \\
\hline & \multicolumn{2}{|c|}{ Adada } & \multicolumn{2}{|l|}{ Oji } & \multicolumn{2}{|c|}{ Ota-Alu } & \multicolumn{2}{|l|}{ Obibia } & \multicolumn{2}{|l|}{ Mamu } & \multicolumn{2}{|l|}{ Ezu } & & \\
\hline & UpS & $\mathrm{DnS}$ & UpS & $\mathrm{DnS}$ & UpS & $\mathrm{DnS}$ & UpS & $\mathrm{DnS}$ & UpS & $\mathrm{DnS}$ & UpS & $\mathrm{DnS}$ & & \\
\hline $\mathrm{pH}$ & 6.8 & 5.9 & 6.3 & 6.4 & 5.9 & 5.6 & 5.6 & 6.1 & 6.2 & 5.7 & 6.4 & 6.3 & $6.5-8.5(7.5)^{\mathrm{d}}$ & - \\
\hline $\mathrm{EC}$ & 15.25 & 14.83 & 41.62 & 44.92 & 39.26 & 33.15 & 31.74 & 33.65 & 22.50 & 24.06 & 45.79 & 43.60 & 1000 & 1,000 \\
\hline $\mathrm{C}^{\mathrm{e}}$ & 10.01 & 34.93 & 20.01 & 114.73 & 19.95 & 0.01 & 24.3 & 9.97 & 79.5 & 64.7 & 98.16 & 105.4 & - & - \\
\hline $\mathrm{Ca}^{2+}$ & 8.01 & 40.08 & 40.08 & 16.03 & 5.61 & 40.08 & 40.08 & 10.42 & 10.99 & 8.6 & 12.10 & 23.9 & 75 & 75 \\
\hline $\mathrm{Mg}^{2+}$ & 43.64 & 63.23 & 34.04 & 48.64 & 97.28 & 24.32 & 1045.8 & 72.96 & 102.64 & 34.05 & 168.19 & 110.2 & 30 & 50 \\
\hline $\mathrm{Cl}^{-}$ & 0.51 & 3.22 & 0.01 & 9.55 & 3.17 & 0.01 & 10.45 & 1.59 & 10.5 & 88.6 & 19.9 & 12.5 & 250 & 250 \\
\hline $\mathrm{K}^{+}$ & 0.01 & 0.33 & 0.01 & 0.72 & 0.01 & 0.04 & 0.27 & 0.05 & 0.17 & 5.20 & 8.70 & 0.91 & 10 & - \\
\hline $\mathrm{NO}_{3}$ & 0.01 & 0.11 & 0.07 & 0.18 & 0.04 & 0.04 & 0.09 & 0.11 & 0.7 & 0.51 & 11.6 & 2.1 & 45 & 50 \\
\hline $\mathrm{PO}_{4}^{3-}$ & 0.01 & 0.18 & 0.04 & 0.20 & 0.02 & 0.02 & 0.14 & 0.15 & 0.9 & 0.92 & 0.54 & 0.78 & - & - \\
\hline $\mathrm{Na}^{+}$ & 0.07 & 0.11 & 0.53 & 0.30 & 1.22 & 1.51 & 0.05 & 0.18 & 0.09 & 0.17 & 1.36 & 1.06 & 200 & 200 \\
\hline $\mathrm{HCO}_{3}{ }^{-}$ & 0.92 & 1.24 & 1.62 & 1.98 & 2.04 & 2.75 & 0.93 & 1.30 & 0.50 & 0.97 & 1.75 & 2.51 & 500 & 600 \\
\hline $\mathrm{Zn}^{2+}$ & 0.01 & 2.63 & 0.01 & 1.52 & 0.01 & 0.05 & 2.44 & 0.01 & 2.9 & 5.0 & 16.5 & 8.4 & 3 & 3 \\
\hline $\mathrm{Fe}^{2+}$ & 0.01 & 0.01 & 0.01 & 0.04 & 0.01 & 0.01 & 0.01 & 0.01 & 0.05 & 0.05 & 0.04 & 0.65 & 0.3 & 0.3 \\
\hline $\mathrm{Mn}^{2+}$ & 0.01 & 0.01 & 0.01 & 0.01 & 0.02 & 0.5 & 0.02 & 0.01 & 0.03 & 0.76 & 0.14 & 0.05 & 0.4 & 0.2 \\
\hline TDS & 501.6 & 750 & 259 & 130 & 102 & 115 & 120 & 330 & 287 & 762 & 382 & 319 & 500 & - \\
\hline TSS & 520 & 11.5 & 77 & 38 & 45 & 47 & 87 & 92.0 & 64 & 2.8 & 15 & 102 & 500 & - \\
\hline $\operatorname{Temp}\left({ }^{\circ} \mathrm{C}\right)$ & 26.6 & 25.6 & 26.1 & 24.3 & 26.9 & 26.3 & 25.7 & 23.3 & 25.1 & 26.8 & 24.4 & 23.6 & - & Ambient \\
\hline $\mathrm{SO}_{4}$ & 75.2 & 36.8 & 35.0 & 24.9 & 18.43 & 23.08 & 17.08 & 19.6 & 13.5 & 21.6 & 48.6 & 62.4 & 250 & 250 \\
\hline DO & 3.5 & 2.3 & 1.6 & 4.8 & 4.2 & 7.2 & 3.6 & 4.1 & 3.9 & 4.2 & 3.1 & 2.7 & 5 & - \\
\hline BOD & 1.8 & 6.2 & 2.5 & 2.3 & 1.8 & 6.8 & 1.8 & 7.5 & 1.2 & 3.6 & 4.4 & 1.5 & 5 & - \\
\hline Turbidity $(\mathrm{FTU})^{\mathrm{f}}$ & 3.57 & 15.5 & 9.5 & 6.08 & 5.6 & 10 & 8.5 & 9.5 & 12.0 & 5.6 & 12.6 & 22.7 & 5 & - \\
\hline Total coliform & 1005 & 980 & 1260 & 1441 & 825 & 680 & 520 & 840 & 752 & 1158 & 1200 & 1089 & 0 & - \\
\hline
\end{tabular}

${ }^{a} U p S$ upstream, $D n S$ downstream, except order wise stated, all parameters are measured in $\mathrm{mg} / \mathrm{l}$

${ }^{\mathrm{b}}$ Value that is above the maximum permissible limits are underlined

${ }^{\mathrm{c}}$ Maximum permissible limits for drinking water

${ }^{\mathrm{d}}$ Mean

${ }^{\mathrm{e}}$ Carbon in form of dissolved organic carbon (DOC)

${ }^{\mathrm{f}}$ Formacin turbidity unit

$\mathrm{CaCl}_{2}$ and $\mathrm{MgCl}_{2}$ during leaching of minerals, viz. gallite, sylvite, carnallite and bischofite-nephelines and saline deposits (Dinka et al. 2015). Primarily, existence of $\mathrm{SO}_{4}{ }^{2-}$ is explained by rock weathering and dissolution of sulfuric minerals-pyrite and gypsum, together with decomposition-cum-oxidation of crustal sulfide, and fossil fuel (Dinka et al. 2015; Barbieri et al. 2018), while Okogbue et al. (2012) traced its source to anthropogenic activities-agricultural and domestic wastes. Presence of $\mathrm{HCO}_{3}{ }^{-}$is associated with atmospheric actions (dissolved $\mathrm{CO}_{2}$ in rainwater), organic decomposition and dissolution of carbonic acid $\left(\mathrm{H}_{2} \mathrm{CO}_{3}\right)$ and carbonate rocks such as limestone, dolomite and magnetite (Dinka et al. 2015).

\section{Potential toxic metals (PTM) and biological parameter}

PTM detected in the water sample were iron $(\mathrm{Fe})$, zinc $(\mathrm{Zn})$ and manganese $(\mathrm{Mn})$ metals. Their average concentrations in rainy and dry seasons were $0.08,3.29$ and $0.13 \mathrm{mg} / \mathrm{l}$ and $0.34,3.50$ and $2.43 \mathrm{mg} / \mathrm{l}$, respectively (Table 7 ). Reduced values in wet season are explained by high river discharge and dilution, while higher dry season values are reckoned with anthropogenic influences and low river discharge.

BOD ranged from 1.20 to $7.50 \mathrm{mg} / \mathrm{l}$ and 1.80 to $8.10 \mathrm{mg} / \mathrm{l}$ in rainy and dry seasons, and coliform counts were 1520-1441 and 468-1028 in wet and dry seasons, 
Table 6 Dry season's hydrochemistry of surface water from Mamu River basin

\begin{tabular}{|c|c|c|c|c|c|c|c|c|c|c|c|c|c|c|}
\hline \multirow[t]{3}{*}{ Parameter $^{\mathrm{a}}$} & \multicolumn{12}{|l|}{ River $^{\mathrm{b}}$} & \multirow[t]{3}{*}{ WHO $(2007)^{\mathrm{c}}$} & \multirow[t]{3}{*}{ SON $(2007)^{\mathrm{c}}$} \\
\hline & \multicolumn{2}{|l|}{ Adada } & \multicolumn{2}{|l|}{ Oji } & \multicolumn{2}{|c|}{ Ota-Alu } & \multicolumn{2}{|l|}{ Obibia } & \multicolumn{2}{|l|}{ Mamu } & \multicolumn{2}{|l|}{ Ezu } & & \\
\hline & UpS & DnS & UpS & $\mathrm{DnS}$ & UpS & DnS & UpS & DnS & UpS & DnS & UpS & $\mathrm{DnS}$ & & \\
\hline $\mathrm{pH}$ & 5.7 & 6.2 & 5.4 & 5.1 & 5.3 & 6.2 & 6.8 & 6.2 & 6.8 & 6.2 & 6.6 & 6.9 & $6.5-8.5(7.5)^{\mathrm{d}}$ & - \\
\hline $\mathrm{EC}$ & 14.46 & 15.03 & 41.95 & 43.82 & 50.11 & 52.67 & 33.06 & 33.27 & 23.68 & 24.81 & 47.09 & 48.15 & 1000 & 1000 \\
\hline $\mathrm{C}^{\mathrm{e}}$ & 24.3 & 36.85 & 10.01 & 60.5 & 0.01 & 40.5 & 89.77 & 10.02 & 56.5 & 90.24 & 112.4 & 111.4 & - & - \\
\hline $\mathrm{Ca}^{2+}$ & 3.21 & 42.1 & 41.0 & 6.1 & 6.01 & 60.41 & 40.1 & 8.02 & 15.5 & 12.80 & 30.1 & 32.5 & 75 & 75 \\
\hline $\mathrm{Mg}^{2+}$ & 48.78 & 24.32 & 38.91 & 24.32 & 19.46 & 34.05 & 1072.8 & 38.91 & 54.6 & 46.03 & 178 & 120 & 30 & 50 \\
\hline $\mathrm{Cl}^{-}$ & 6.24 & 5.24 & 6.07 & 11.5 & 8.34 & 7.21 & 10.51 & 7.68 & 17.4 & 5.6 & 11.3 & 3.6 & 250 & 250 \\
\hline $\mathrm{K}^{+}$ & 0.82 & 0.57 & 0.95 & 0.9 & 0.84 & 1.55 & 2.38 & 0.93 & 1.04 & 6.93 & 1.04 & 7.41 & 10 & - \\
\hline $\mathrm{NO}_{3}^{-}$ & 0.07 & 0.07 & 0.70 & 0.24 & 0.04 & 0.08 & 0.09 & 0.99 & 0.9 & 0.06 & 1.08 & 2.5 & 45 & 50 \\
\hline $\mathrm{PO}_{4}^{3-}$ & 2.3 & 0.20 & 0.16 & 0.7 & 0.02 & 0.34 & 10.6 & 0.94 & 2.04 & 1.15 & 0.08 & 2.2 & - & - \\
\hline $\mathrm{Na}^{+}$ & 0.13 & 0.23 & 0.66 & 0.34 & 1.16 & 0.98 & 0.14 & 0.32 & 0.10 & 0.23 & 1.54 & 1.70 & 200 & 200 \\
\hline $\mathrm{HCO}_{3}{ }^{-}$ & 0.88 & 1.33 & 1.71 & 1.88 & 2.25 & 2.53 & 1.47 & 3.86 & 1.06 & 1.03 & 1.83 & 1.97 & 500 & 600 \\
\hline $\mathrm{Zn}^{2+}$ & 0.01 & 6.40 & 0.07 & 3.0 & 0.01 & 6.01 & 3.01 & 0.01 & 3.51 & 7.12 & 2.25 & 10.6 & 3 & 3 \\
\hline $\mathrm{Fe}^{2+}$ & 0.08 & 0.8 & 0.06 & 0.25 & 0.01 & 0.03 & 0.04 & 0.02 & 0.04 & 0.72 & 0.85 & 1.2 & 0.3 & 0.3 \\
\hline $\mathrm{Mn}^{2+}$ & 2.1 & 7.5 & 0.4 & 7.5 & 0.02 & 2.2 & 6.0 & 2.0 & 0.03 & 0.94 & 0.25 & 0.21 & 0.4 & 0.2 \\
\hline TDS & 567 & 774 & 277 & 140 & 102 & 95 & 132 & 350 & 290 & 800 & 400 & 349 & 500 & - \\
\hline TSS & 720 & 530 & 82 & 41 & 45 & 55 & 95 & 101.3 & 72 & 39 & 22 & 115 & 500 & - \\
\hline Temp $\left({ }^{\circ} \mathrm{C}\right)$ & 27 & 26.7 & 26.3 & 24.3 & 26.9 & 26.1 & 26.4 & 24.2 & 25.6 & 27 & 25.1 & 26.5 & - & Ambient \\
\hline $\mathrm{SO}_{4}$ & 78.7 & 78.7 & 28.8 & 24.9 & 18.43 & 29.41 & 88.03 & 29.8 & 18.7 & 25.8 & 50.1 & 78.0 & 250 & 250 \\
\hline DO & 3.8 & 3.8 & 6.1 & 4.8 & 4.2 & 3.1 & 4.2 & 4.7 & 4.2 & 5.5 & 4.9 & 3.8 & 5 & - \\
\hline BOD & 2.2 & 2.2 & 3.0 & 2.3 & 1.8 & 4.7 & 3.2 & 8.1 & 2.2 & 4.11 & 5.6 & 2.2 & 5 & - \\
\hline Turbidity $(F T U)^{\mathrm{f}}$ & 4.2 & 28.5 & 2.5 & 6.08 & 5.6 & 7.5 & 10.2 & 12.6 & 14.1 & 7.5 & 14.9 & 38.8 & 5 & - \\
\hline Total coliform & 821 & 798 & 1011 & 1028 & 530 & 641 & 468 & 699 & 696 & 731 & 882 & 805 & 0 & - \\
\hline
\end{tabular}

${ }^{a} U p S$ upstream, $D n S$ downstream, except order wise stated, all parameters are measured in $\mathrm{mg} / \mathrm{l}$

${ }^{\mathrm{b}}$ Value that is above the maximum permissible limits are underlined

${ }^{\mathrm{c}}$ Maximum permissible limits for drinking water

${ }^{\mathrm{d}}$ Mean

${ }^{\mathrm{e}}$ Carbon in form of dissolved organic carbon (DOC)

${ }^{\mathrm{f}}$ Formacin turbidity unit

respectively (Table 7). Higher coliform count, in addition to $\mathrm{NO}_{3}{ }^{-}$and $\mathrm{Cl}^{-}$, in the rainy season connotes poor sanitation and influx of human biological wastes through runoff (Tables 5, 6, 7).

\section{Correlation analysis-cum-paired sample $t$ test of water samples in the rainy and dry seasons}

Correlation analysis revealed a slight increase of the hydro geo- chemical parameters of the water samples in the dry season when compared to the rainy season (Tables 5, 6, 7). Paired sample T-test indicates the level of significant difference exhibited by parameters (Table 8 ). From the table, there was no significant difference between the concentration level in the rainy season and the dry season as regard $\mathrm{pH}(p=0.944), \mathrm{EC}(p=0.101), \mathrm{Ce}(p=0.584)$, $\mathrm{Ca}^{2+}(p=0.193), \mathrm{Mg}^{2+}(p=0.215), \mathrm{Cl}^{-}(p=0.511)$,
$\mathrm{K}+(p=0.427), \mathrm{NO}_{3}(p=0.433), \mathrm{PO}_{4}{ }^{3-}(p=0.128)$, $\mathrm{Na}^{+}(p=0.345), \mathrm{HCO}_{3}{ }^{-}(p=0.248), \mathrm{Zn}^{2+}(p=0.885)$, TSS $(p=0.150), \mathrm{SO}_{4}(p=0.069), \mathrm{DO}(p=0.263), \mathrm{BOD}$ $(p=0.969)$ and turbidity $(p=0.175)$. Thus, we accept the null hypothesis, which posits that there is no significant difference in the concentration level of analyzed parameters in the water samples in the rainy and dry seasons. The implication of this result is that seasonality had no effects in the afore-mentioned parameters in the drainage basin.

Significant difference, however, existed for $\mathrm{Fe}^{2+}$ $(p=0.019), \mathrm{Mn}^{2+}(p=0.021)$, TDS $(p=0.013)$, temp $(p=0.024)$ and total coliform $(p<0.001)$. For Fe ${ }^{2+}, \mathrm{Mn}^{2+}$, TDS and temperature, we accept the alternative hypothesis which states that there is a significant difference in the concentration level of analyzed parameters in the water sample parameters. Thus, it implies that $\mathrm{Fe}^{2+}, \mathrm{Mn}^{2+}$, TDS 
Table 7 Descriptive statistics of the analyzed hydro-geochemical properties

\begin{tabular}{|c|c|c|c|c|c|c|c|c|c|}
\hline \multirow[t]{2}{*}{ Parameter $^{\mathrm{a}}$} & \multirow{2}{*}{$\begin{array}{l}\text { No. of } \\
\text { samples }\end{array}$} & \multicolumn{4}{|c|}{ Rainy season } & \multicolumn{4}{|c|}{ Dry season } \\
\hline & & Max & Min & Mean & Standard deviation & Max & Min & Mean & Standard deviation \\
\hline $\mathrm{pH}$ & 12 & 6.80 & 5.60 & 6.10 & 0.37 & 6.90 & 5.10 & 6.12 & 0.62 \\
\hline EC & 12 & 45.79 & 14.83 & 32.53 & 11.14 & 52.67 & 14.46 & 35.68 & 13.62 \\
\hline $\mathrm{C}$ & 12 & 114.73 & 0.01 & 48.47 & 41.59 & 112.40 & 0.01 & 53.54 & 39.87 \\
\hline $\mathrm{Ca}^{2+}$ & 12 & 40.08 & 5.61 & 21.33 & 14.58 & 60.41 & 3.21 & 24.82 & 18.67 \\
\hline $\mathrm{Mg}^{2+}$ & 12 & 1045.8 & 24.32 & 157.75 & 283.96 & 1072.8 & 19.46 & 141.68 & 296.85 \\
\hline $\mathrm{Cl}^{-}$ & 12 & 88.60 & 0.01 & 13.33 & 24.50 & 17.40 & 3.60 & 8.39 & 3.77 \\
\hline $\mathrm{K}^{+}$ & 12 & 8.70 & 0.01 & 1.37 & 2.73 & 7.41 & 0.57 & 2.11 & 2.41 \\
\hline $\mathrm{NO}_{3}$ & 12 & 11.60 & 0.01 & 1.30 & 3.30 & 2.5 & 0.04 & 0.57 & 0.73 \\
\hline $\mathrm{PO}_{4}{ }^{3-}$ & 12 & 0.92 & 0.01 & 0.33 & 0.36 & 10.6 & 0.02 & 1.73 & 2.92 \\
\hline $\mathrm{Na}^{+}$ & 12 & 1.51 & 0.05 & 0.55 & 0.57 & 1.70 & 0.10 & 0.62 & 0.58 \\
\hline $\mathrm{HCO}_{3}^{-}$ & 12 & 2.75 & 0.50 & 1.54 & 0.69 & 3.86 & 0.88 & 1.82 & 0.82 \\
\hline $\mathrm{Zn}^{2+}$ & 12 & 16.50 & 0.01 & 3.29 & 4.88 & 10.06 & 0.01 & 3.50 & 3.45 \\
\hline $\mathrm{Fe}^{2+}$ & 12 & 0.65 & 0.01 & 0.08 & 0.18 & 1.2 & 0.01 & 0.34 & 0.43 \\
\hline $\mathrm{Mn}^{2+}$ & 12 & 0.76 & 0.01 & 0.13 & 0.24 & 7.5 & 0.02 & 2.43 & 2.89 \\
\hline TDS & 12 & 762 & 102 & 338.13 & 230.36 & 800 & 95 & 356.33 & 244.44 \\
\hline TSS & 12 & 520 & 2.80 & 91.78 & 138.77 & 720 & 22 & 159.78 & 222.82 \\
\hline $\operatorname{Temp}\left({ }^{\circ} \mathrm{C}\right)$ & 12 & 26.90 & 23.30 & 25.39 & 1.24 & 27 & 24.20 & 26.01 & 0.10 \\
\hline $\mathrm{SO}_{4}$ & 12 & 75.20 & 13.50 & 33.02 & 19.60 & 88.03 & 18.43 & 45.78 & 27.20 \\
\hline DO & 12 & 7.20 & 1.60 & 3.77 & 1.41 & 6.10 & 3.10 & 4.43 & 0.82 \\
\hline BOD & 12 & 7.50 & 1.20 & 3.45 & 2.24 & 8.10 & 1.80 & 3.47 & 1.88 \\
\hline Turbidity (FTU) & 12 & 22.7 & 3.57 & 10.10 & 5.23 & 38.80 & 2.50 & 12.71 & 10.74 \\
\hline Total coliform & 12 & 1441 & 520 & 979.17 & 266.41 & 1028 & 468 & 959.17 & 170 \\
\hline
\end{tabular}

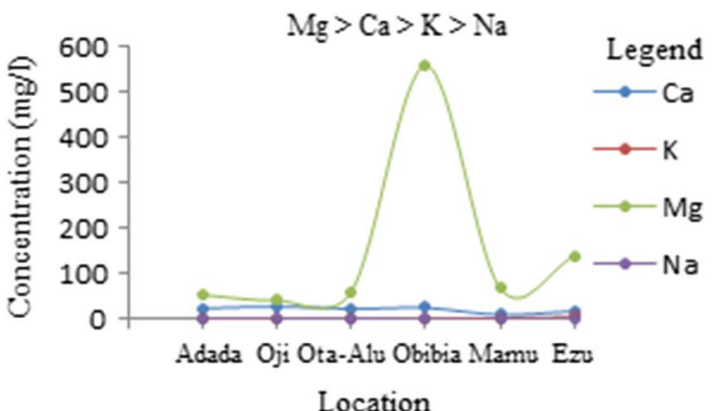

Location

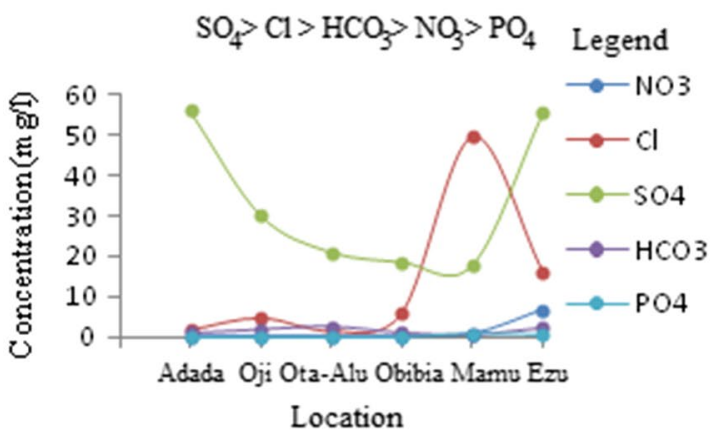

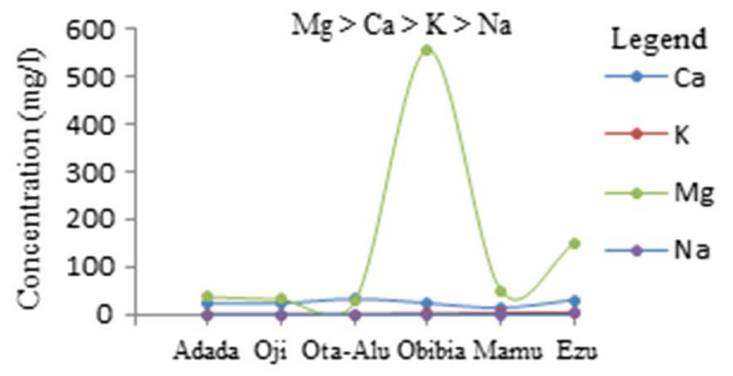

Location

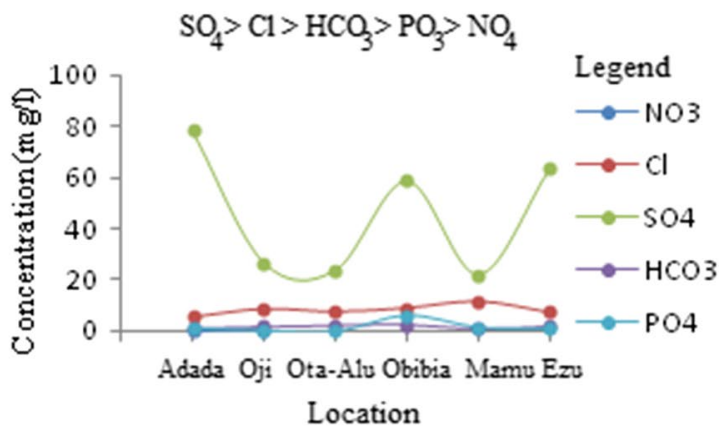

Fig. 5 Order of geochemical distribution 
Table 8 Paired sample $t$ ' test of the compositions in rainy and dry seasons

\begin{tabular}{|c|c|c|c|c|c|}
\hline Parameters & Rainy & Dry & Mean difference & $t$ & $p$ value \\
\hline $\mathrm{pH}$ & $6.10 \pm 0.37$ & $6.12 \pm 0.62$ & -0.02 & -0.072 & 0.944 \\
\hline EC & $32.53 \pm 11.14$ & $35.68 \pm 13.62$ & -3.14 & -1.788 & 0.101 \\
\hline $\mathrm{Ce}$ & $48.47 \pm 41.59$ & $53.54 \pm 39.87$ & -5.07 & -0.563 & 0.584 \\
\hline $\mathrm{Ca}^{2+}$ & $21.33 \pm 14.58$ & $24.82 \pm 18.67$ & -3.49 & -1.387 & 0.193 \\
\hline $\mathrm{Mg}^{2+}$ & $153.75 \pm 283.96$ & $141.68 \pm 296.85$ & 12.07 & 1.317 & 0.215 \\
\hline Cl- & $13.33 \pm 24.50$ & $8.39 \pm 3.77$ & 4.94 & 0.679 & 0.511 \\
\hline $\mathrm{K}^{+}$ & $1.37 \pm 2.73$ & $2.11 \pm 2.41$ & -0.75 & -0.824 & 0.427 \\
\hline $\mathrm{NO}_{3}$ & $1.30 \pm 3.30$ & $0.57 \pm 0.73$ & 0.73 & 0.813 & 0.433 \\
\hline $\mathrm{PO}_{4}^{3-}$ & $0.33 \pm 0.36$ & $1.73 \pm 2.92$ & -1.40 & -1.648 & 0.128 \\
\hline $\mathrm{Na}^{+}$ & $0.55 \pm 0.57$ & $0.63 \pm 0.58$ & -0.07 & -0.986 & 0.345 \\
\hline $\mathrm{HCO}_{3}^{-}$ & $1.54 \pm 0.69$ & $1.82 \pm 0.82$ & -0.27 & -1.219 & 0.248 \\
\hline $\mathrm{Zn}^{2+}$ & $3.29 \pm 4.88$ & $3.50 \pm 3.42$ & -0.21 & -0.148 & 0.885 \\
\hline $\mathrm{Fe}^{2+}$ & $0.08 \pm 0.18$ & $0.34 \pm 0.43$ & -0.27 & -2.761 & $0.019^{\mathrm{a}}$ \\
\hline $\mathrm{Mn}^{2+}$ & $0.13 \pm 0.24$ & $2.43 \pm 2.89$ & -2.30 & -2.695 & $0.021^{\mathrm{a}}$ \\
\hline TDS & $338.13 \pm 230.36$ & $356.33 \pm 244.66$ & -18.20 & -2.980 & $0.013^{\mathrm{a}}$ \\
\hline TSS & $91.77 \pm 138.77$ & $159.78 \pm 222.82$ & -68.00 & -1.547 & 0.150 \\
\hline $\operatorname{Temp}\left({ }^{\circ} \mathrm{C}\right)$ & $25.39 \pm 1.24$ & $26.01 \pm 1.00$ & -0.62 & -2.609 & $0.024^{\mathrm{a}}$ \\
\hline $\mathrm{SO}_{4}$ & $33.02 \pm 19.60$ & $45.78 \pm 27.20$ & -12.77 & -2.011 & 0.069 \\
\hline DO & $3.77 \pm 1.41$ & $4.43 \pm 0.82$ & -0.66 & -1.179 & 0.263 \\
\hline BOD & $3.45 \pm 2.24$ & $3.47 \pm 1.88$ & -0.02 & -0.039 & 0.969 \\
\hline Turbidity (FTU) & $10.10 \pm 5.23$ & $12.71 \pm 10.74$ & -2.61 & -1.450 & 0.175 \\
\hline Total coliform & $979.17 \pm 266.41$ & $759.17 \pm 169.99$ & 220.00 & 5.693 & $<0.001^{\mathrm{a}}$ \\
\hline
\end{tabular}

Statistics used: paired samples $t$ test

${ }^{\text {a }}$ Parameters with significant difference and temperature exhibit temporal variation corroborating (Barbieri et al. 2018).

\section{Discussion of results}

\section{Characterization of water quality parameters}

The chemical characteristics of water determine its usefulness for industrial, agricultural and domestic purposes. The temperature $23.30-27.0{ }^{\circ} \mathrm{C}$ of the sampled water was at ambient level. Such temperature supports ionization and dissolution at relatively low levels (Gideon et al. 2013). The pH was slightly acidic and ranked higher than World Health Organization (2007) recommended standards (Tables 5, 6). Such acidity can cause corrosion when in contact with pipes and can also increase the solubility of PTMs.

The TDS categorized the rivers as freshwater (Table 8) and was within the WHO (2007) standard (Tables 5, 6). TDS grading suggested that two-thirds of the samples could be considered fit for domestic use (Table 9). EC was also within limits and could rate the water satisfactory for any purposes (Tables 5, 6, 9).

Turbidity is slightly above the WHO limit (Tables 5, 6). The high turbidity may hinder light transmission through the water and thus inhibits biological activities, which results in increased suspended matter, and that invariably acts as a sink for potential toxic substances (Gideon et al. 2013). In all sampled sub-basins, TSS conformed to WHO (2007) standard with exception of Adada, where intensive agricultural activities could be an explanation. Dissolved oxygen averaging 3.77 and $4.43 \mathrm{mg} / \mathrm{l}$ for the different seasons (Table 7) is hinting that the basin could support aquatic productivity. However, DO did not comply with WHO (2007) guideline in some locations (Tables 5, 6).

The order of distribution of cations and anions presented in Fig. 5 shows that the pattern of ionic distribution is the same for both seasons. This agrees with the results of the Stiff (1940) plots which suggest that the same geochemical characteristics dominated between both seasons as revealed by the similarity in Stiff diagram's geometry (Figs. 6, 7). Therefore, there are no appreciable changes in the water type between seasons.

Apart from $\mathrm{Mg}^{2+}$, other soluble cations were below WHO (2007) limit (Tables 5, 6). The high $\mathrm{Mg}^{2+}$, particularly at Obibia upstream, could be occasioned by high solubility and weak biological activity (Dinka et al. 2015). All anions present in the water were below relevant guidelines (Tables 5, 6 ), thus within the desirable limits for domestic uses and suits irrigation practice (Table 8). Potential toxic metals 
Table 9 Domestic and irrigation water class based on hydrochemicals

\begin{tabular}{|c|c|c|c|c|c|c|c|c|}
\hline \multirow[t]{2}{*}{ Purpose } & \multirow[t]{2}{*}{ Quality parameter } & \multirow[t]{2}{*}{ Range (mg/l) } & \multirow[t]{2}{*}{ Classification } & \multicolumn{2}{|c|}{ Rainy season } & \multicolumn{2}{|c|}{ Dry season } & \multirow[t]{2}{*}{ References } \\
\hline & & & & $\begin{array}{l}\text { No. of } \\
\text { sam- } \\
\text { ples }\end{array}$ & $\%$ of samples & $\begin{array}{l}\text { No. of } \\
\text { sam- } \\
\text { ples }\end{array}$ & $\%$ of samples & \\
\hline \multirow[t]{17}{*}{ Domestic } & \multirow[t]{4}{*}{ TDS } & $<1000$ & Freshwater & 12 & 100 & 12 & 100 & \multirow{4}{*}{$\begin{array}{l}\text { Freeze and Cherry } \\
\quad(1979)\end{array}$} \\
\hline & & $1000-10,000$ & Brackish water & 0 & 0 & 0 & 0 & \\
\hline & & $10,000-100,000$ & Saline water & 0 & 0 & 0 & 0 & \\
\hline & & $>100,000$ & Brine & 0 & 0 & 0 & 0 & \\
\hline & \multirow[t]{5}{*}{ TDS } & $<300$ & Excellent & 6 & 50 & 6 & 50 & \multirow{5}{*}{$\begin{array}{c}\text { WHO (2007); Eyank- } \\
\text { ware et al. (2017) }\end{array}$} \\
\hline & & $300-600$ & Good & 4 & 33.33 & 4 & 33.33 & \\
\hline & & $600-900$ & Fair & 2 & 16.67 & 2 & 16.67 & \\
\hline & & $900-1000$ & Poor & 0 & 0 & 0 & 0 & \\
\hline & & $>1000$ & Unacceptable & 0 & 0 & 0 & 0 & \\
\hline & \multirow[t]{3}{*}{ Chloride } & $<200$ & Most desirable limit & 12 & 100 & 12 & 100 & \multirow{3}{*}{$\begin{array}{l}\text { WHO (2007); Nganje } \\
\text { et al. (2015) }\end{array}$} \\
\hline & & $200-600$ & & 0 & 0 & 0 & 0 & \\
\hline & & $>600$ & $\begin{array}{l}\text { Maximum allowable } \\
\text { limit }\end{array}$ & 0 & 0 & 0 & 0 & \\
\hline & \multirow[t]{2}{*}{ Nitrate } & $<45$ & \multirow[t]{2}{*}{ Most desirable limit } & 12 & 100 & 12 & 100 & \multirow{2}{*}{$\begin{array}{l}\text { WHO (2007); Nganje } \\
\text { et al. (2015) }\end{array}$} \\
\hline & & $>45$ & & 0 & 0 & 0 & 0 & \\
\hline & \multirow[t]{3}{*}{ Sulfate } & $<200$ & Most desirable limit & 12 & 100 & 12 & 100 & \multirow{3}{*}{$\begin{array}{l}\text { WHO (2007); Nganje } \\
\text { et al. (2015) }\end{array}$} \\
\hline & & $200-400$ & & 0 & 0 & 0 & 0 & \\
\hline & & $>400$ & $\begin{array}{l}\text { Maximum allowable } \\
\text { limit }\end{array}$ & 0 & 0 & 0 & 0 & \\
\hline \multirow[t]{14}{*}{ Irrigation } & \multirow[t]{4}{*}{$\mathrm{EC}$} & $<250$ & Excellent & 12 & 100 & 12 & 100 & \multirow[t]{4}{*}{ Todd (1980) } \\
\hline & & $250-750$ & Permissible & 0 & 0 & 0 & 0 & \\
\hline & & $750-2000$ & Doubtful & 0 & 0 & 0 & 0 & \\
\hline & & $>2000$ & Unsuitable & 0 & 0 & 0 & 0 & \\
\hline & \multirow[t]{5}{*}{ Chloride } & $<142$ & Excellent & 12 & 100 & 12 & 100 & \multirow[t]{5}{*}{ Nganje et al. (2015) } \\
\hline & & $142-249$ & Good & 0 & 0 & 0 & 0 & \\
\hline & & $249-426$ & Permissible & 0 & 0 & 0 & 0 & \\
\hline & & $426-710$ & Precaution useable & 0 & 0 & 0 & 0 & \\
\hline & & $>710$ & Unsuitable & 0 & 0 & 0 & 0 & \\
\hline & \multirow[t]{5}{*}{ Sulfate } & $<192$ & Excellent & 12 & 100 & 12 & 100 & \multirow[t]{5}{*}{ Nganje et al. (2015) } \\
\hline & & $192-336$ & Good & 0 & 0 & 0 & 0 & \\
\hline & & $336-575$ & Permissible & 0 & 0 & 0 & 0 & \\
\hline & & $575-960$ & Precaution useable & 0 & 0 & 0 & 0 & \\
\hline & & $>960$ & Unsuitable & 0 & 0 & 0 & 0 & \\
\hline
\end{tabular}

$\left(\mathrm{F}^{2+}, \mathrm{Mn}^{2+}\right.$ and $\mathrm{Zn}^{2+}$ ) were higher than the recommended standard in some locations such as Ezu, Mamu and Ota-Alu sub-basins (Tables 5, 6). Such concentration of heavy metal $\left(\mathrm{F}^{2+}\right.$ and $\mathrm{Zn}^{2+}$ ) could lead to increased turbidity (Okogbue et al. 2012) and impact color and taste into water while causing metal pipe scaling (Gideon et al. 2013).

Dissolved organic carbon which is vital in biogeochemical cycling could be an important parameter, but it is yet to be a formal pointer to water quality (Urbaniak and Pietrzak 2011) though it has been an increase in surface waters, and this could be as a result of rising temperature and rainfall, declining acid deposition, land use and nitrogen and $\mathrm{CO}_{2}$ enrichment (Evans et al. 2005). Biochemical oxygen demand was within WHO (2007) permissible limit with exception of two locations (Obibia and Ota-Alu downstream and Ezu Upstream) in each season (Tables 5, 6), while total coliform count was higher than the WHO (2007) limit.

\section{Domestic water quality}

The results of the hydro-geochemical analyses of Mamu surface water suggested that the surface water in both seasons is unfit for consumption and domestic uses following the WHO (2007) and Standard Organization of Nigeria (SON 2007) guidelines (Tables 5, 6). 

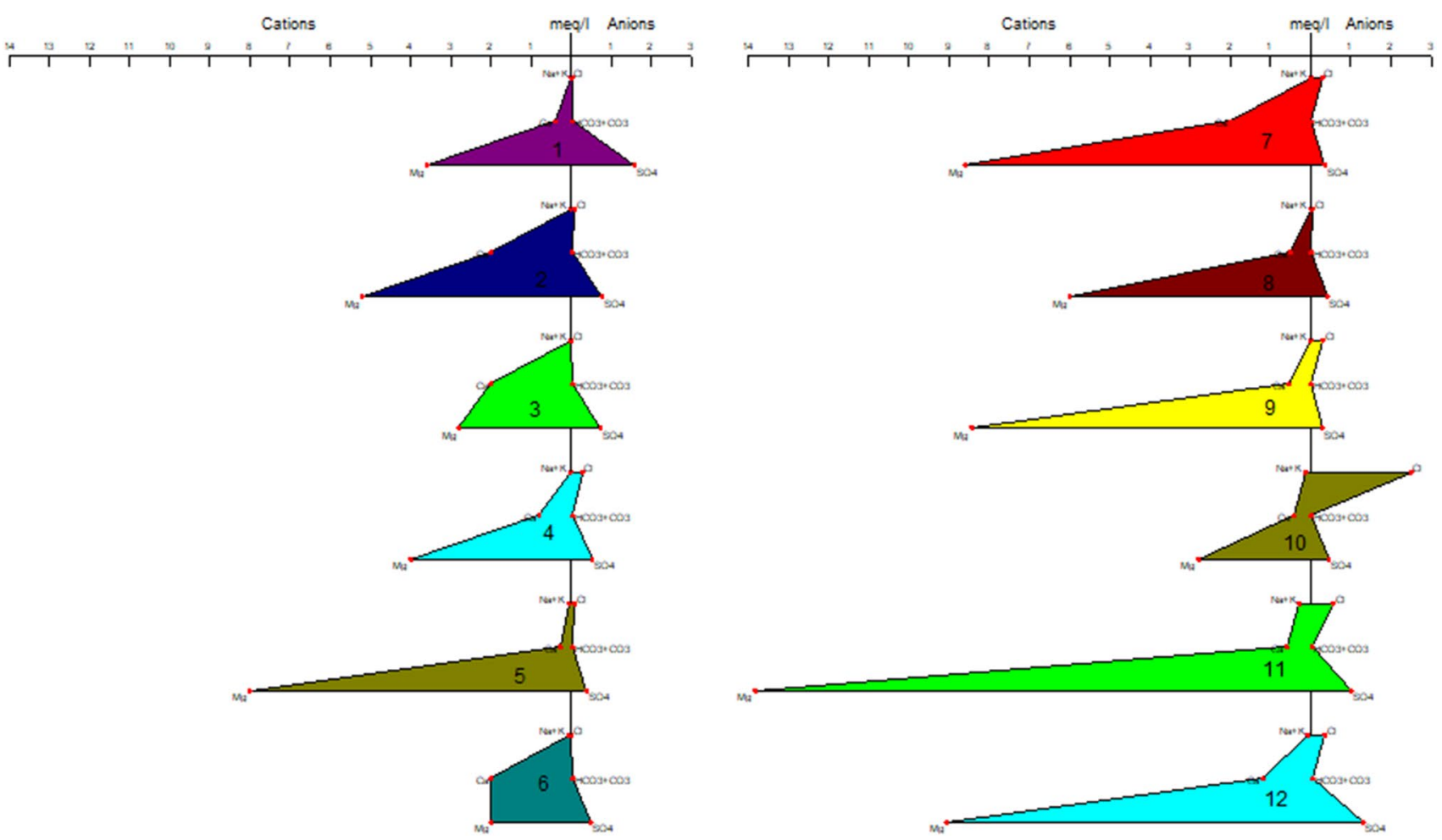

Fig. 6 Stiff plot for the rainy season (water samples 1-12)
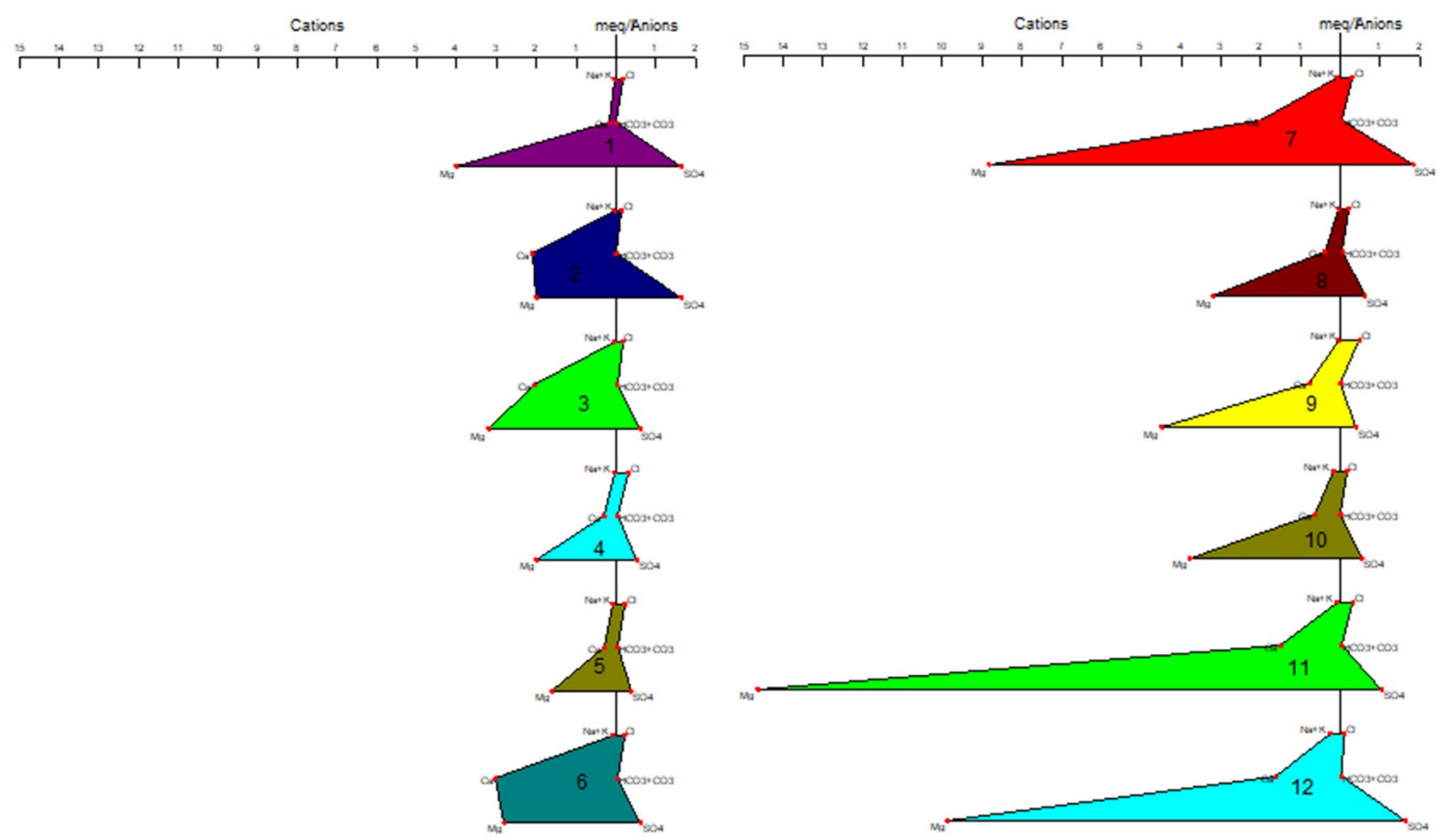

Fig. 7 Dry season Stiff plot for water samples 1-12 
Table 10 Summary of evaluation results of different indices for irrigation water

\begin{tabular}{|c|c|c|c|c|c|c|c|c|c|c|c|}
\hline \multirow[t]{2}{*}{ Rivers } & \multirow[t]{2}{*}{ Location } & \multirow[t]{2}{*}{ Season } & \multicolumn{8}{|c|}{ Water quality criteria } & \multirow[t]{2}{*}{ PI } \\
\hline & & & QWI \% & $\mathrm{Na} \%$ & SAR & $\mathrm{KR}$ & $\mathrm{TH}$ & $\% \mathrm{E}$ & MAR & SSP & \\
\hline \multirow[t]{4}{*}{ Adada } & \multirow[t]{2}{*}{ Upstream } & $\mathrm{RS}$ & 8.79 & 0.15 & 0.013 & 0.001 & 2583 & -19.38 & 84.49 & 0.14 & 1.99 \\
\hline & & DS & 200.68 & 1.79 & 0.025 & 0.003 & 2600 & -21.81 & 93.83 & 0.25 & 2.05 \\
\hline & \multirow[t]{2}{*}{ Downstream } & $\mathrm{RS}$ & 19.50 & 0.42 & 0.015 & 0.001 & 5166 & 44.01 & 61.20 & 0.11 & 1.18 \\
\hline & & DS & 815.20 & 1.19 & 0.040 & 0.003 & 3321 & -2.04 & 36.62 & 0.35 & 2.08 \\
\hline \multirow[t]{4}{*}{ Oji } & \multirow[t]{2}{*}{ Upstream } & $\mathrm{RS}$ & 11.10 & 0.72 & 0.087 & 0.007 & 3706 & 34.11 & 45.93 & 0.71 & 2.43 \\
\hline & & DS & 45.28 & 1.97 & 0.104 & 0.008 & 3996 & 37.52 & 48.69 & 0.82 & 2.46 \\
\hline & \multirow[t]{2}{*}{ Downstream } & $\mathrm{RS}$ & 15.82 & 1.55 & 0.053 & 0.005 & 3234 & 29.51 & 75.21 & 0.46 & 2.64 \\
\hline & & DS & 706.48 & 3.92 & 0.087 & 0.011 & 1521 & 4.81 & 79.95 & 1.11 & 5.63 \\
\hline \multirow[t]{4}{*}{ Ota-Alu } & \multirow[t]{2}{*}{ Upstream } & $\mathrm{RS}$ & 8.01 & 1.18 & 0.170 & 0.012 & 5145 & 62.95 & 94.55 & 1.17 & 2.57 \\
\hline & & DS & 4.65 & 7.28 & 0.325 & 0.045 & 1274 & -2.72 & 76.40 & 4.36 & 10.44 \\
\hline & \multirow[t]{2}{*}{ Downstream } & $\mathrm{RS}$ & 52.65 & 2.35 & 0.266 & 0.023 & 3220 & 43.98 & 37.76 & 2.29 & 4.92 \\
\hline & & DS & 216.37 & 2.61 & 0.143 & 0.010 & 4723 & 45.69 & 36.05 & 1.03 & 2.72 \\
\hline \multirow[t]{4}{*}{ Obibia } & \multirow[t]{2}{*}{ Upstream } & $\mathrm{RS}$ & 27.50 & 0.03 & 0.002 & 0.0000 & 54,294 & 94.89 & 96.31 & 0.005 & 0.09 \\
\hline & & DS & 567.40 & 0.23 & 0.006 & 0.0001 & 55,645 & 83.65 & 96.40 & 0.01 & 0.12 \\
\hline & \multirow[t]{2}{*}{ Downstream } & $\mathrm{RS}$ & 12.98 & 0.16 & 0.012 & 0.001 & 4169 & 57.41 & 87.50 & 0.10 & 1.46 \\
\hline & & DS & 191.96 & 2.39 & 0.045 & 0.004 & 2347 & 8.42 & 82.91 & 0.47 & 4.66 \\
\hline \multirow{4}{*}{$\begin{array}{l}\text { Mamu (main } \\
\text { channel) }\end{array}$} & \multirow[t]{2}{*}{ Upstream } & $\mathrm{RS}$ & 24.32 & 0.23 & 0.012 & 0.001 & 5682 & 64.52 & 90.33 & 0.08 & 0.70 \\
\hline & & DS & 27.01 & 1.60 & 0.017 & 0.001 & 3505 & 32.57 & 77.88 & 0.14 & 1.61 \\
\hline & \multirow[t]{2}{*}{ Downstream } & $\mathrm{RS}$ & 87.45 & 11.18 & 0.037 & 0.004 & 2133 & -34.95 & 79.84 & 0.40 & 2.71 \\
\hline & & DS & 215.00 & 10.85 & 0.042 & 0.004 & 2942 & 39.43 & 78.24 & 0.39 & 2.11 \\
\hline \multirow[t]{4}{*}{ Ezu } & \multirow[t]{2}{*}{ Upstream } & $\mathrm{RS}$ & 59.23 & 5.29 & 0.143 & 0.008 & 9015 & 43.33 & 93.29 & 0.75 & 1.49 \\
\hline & & DS & 174.85 & 1.22 & 0.151 & 0.007 & 10,405 & 53.79 & 85.54 & 0.73 & 1.39 \\
\hline & \multirow[t]{2}{*}{ Downstream } & $\mathrm{RS}$ & 136.01 & 1.44 & 0.129 & 0.008 & 6705 & 29.22 & 82.18 & 0.78 & 1.97 \\
\hline & & DS & 252.33 & 5.64 & 0.195 & 0.011 & 7625 & 33.71 & 78.69 & 1.10 & 2.04 \\
\hline
\end{tabular}

$R S$ rainy season, $D S$ dry season

Fig. 8 Statistical pictogram of Mamu River basin water quality

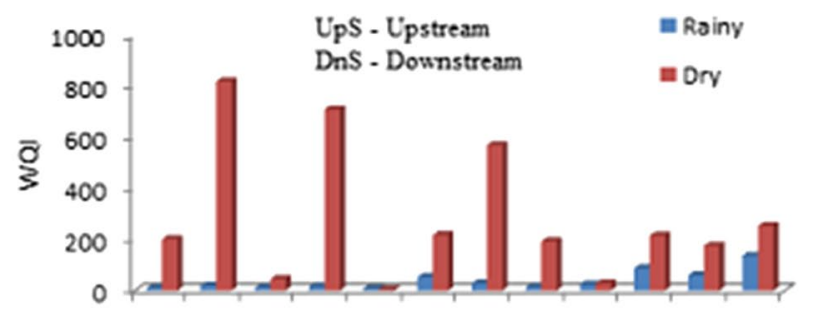

(a)
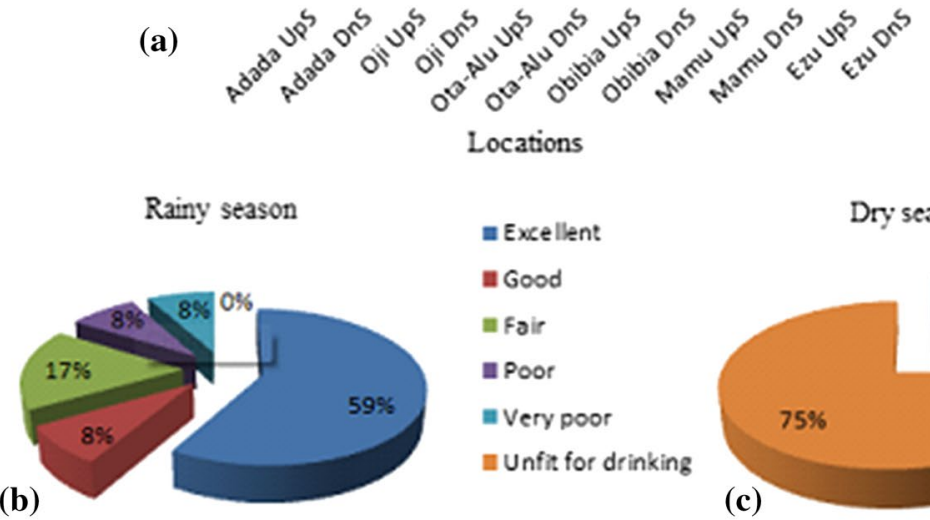

(c)
Excellent

a Good

\pm Fair

alloor

= Very poor

wunfit for drinking
Dry season

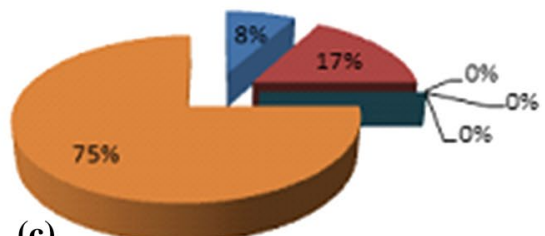

(b) Springer 
QWI revealed that the downstream reaches may have poorer water quality (higher QWI) than the upstream (Table 10, Fig. 8a) which could be explained by large-scale socioeconomic activities and the sink function the river performs at the downstream.

The QWI ranged from 8 to $136 \%$ and 4.65 to $815.2 \%$ in rainy and dry seasons (Table 10) and spanned from excellent to unfit for drinking (Table 10). The QWI values for both seasons suggested that the rainy season has a better water quality, and this agrees with the assertion of Barbieri et al. (2018). A large percentage of the total water samples have QWI values greater than 50, signifying that the water is unfit for drinking but could be suitable for other purposes such as industrial and irrigation (Table 11). The percentage water status for the various rankings as presented in Table 11 is illustrated in Fig. 8b, c.

Poorer quality of the water in dry season as depicted by higher QWI could be attributed to poor river self-purification processes due to lower discharge (lower volume and flow) and greater anthropogenic influences as a result of over dependence on the river resource at that time of the year. Conclusively, the basin water should be treated before utilizing it for drinking or any other domestic purposes.
Table 11 WQI and corresponding water quality status

Table 12 Classification of surface water from River Mamu basin

\begin{tabular}{lllll}
\hline WQI & Status & Rainy season & Dry season & Possible usage \\
\hline $0-25$ & Excellent & 7 & 1 & Drinking, irrigation and industrial \\
$25-50$ & Good & 1 & 2 & Domestic, irrigation and industrial \\
$51-75$ & Fair & 2 & 0 & Irrigation and industrial \\
$76-100$ & Poor & 1 & 0 & Irrigation \\
$101-150$ & Very poor & 1 & 0 & Restricted use for irrigation \\
$>150$ & Unfit for drinking & 0 & 9 & Proper treatment required before use \\
\hline
\end{tabular}

Source: Shodhganga (n.d)

\begin{tabular}{|c|c|c|c|c|c|c|}
\hline \multirow[t]{2}{*}{ Indices } & \multirow[t]{2}{*}{ Range } & \multirow[t]{2}{*}{ Class } & \multicolumn{2}{|c|}{ Number of samples } & \multicolumn{2}{|c|}{ Percentage of samples } \\
\hline & & & Rainy season & Dry season & Rainy season & Dry season \\
\hline \multirow[t]{5}{*}{$\mathrm{Na} \%$} & $<20$ & Excellent & 12 & 12 & 100 & 100 \\
\hline & 20 to 40 & Good & 0 & 0 & 0 & 0 \\
\hline & 40 to 60 & Permissible & 0 & 0 & 0 & 0 \\
\hline & 60 to 80 & Doubtful & 0 & 0 & 0 & 0 \\
\hline & $>80$ & Unsafe & 0 & 0 & 0 & 0 \\
\hline \multirow[t]{4}{*}{$\mathrm{TH}$} & $<75$ & Soft & 0 & 0 & 0 & 0 \\
\hline & 75 to 150 & Moderate & 0 & 0 & 0 & 0 \\
\hline & 150 to 300 & Hard & 0 & 0 & 0 & 0 \\
\hline & $>300$ & Very hard & 12 & 12 & 100 & 100 \\
\hline \multirow[t]{2}{*}{ MAR } & $<50$ & Suitable & 2 & 3 & 16.67 & 25 \\
\hline & $>50$ & Unsuitable & 10 & 9 & 83.33 & 75 \\
\hline \multirow[t]{2}{*}{ SSP } & $<200$ & Suitable & 12 & 12 & 100 & 100 \\
\hline & $>200$ & Unsuitable & 0 & 0 & 0 & 0 \\
\hline \multirow[t]{2}{*}{ KR } & $<1.0$ & Suitable & 12 & 12 & 100 & 100 \\
\hline & $>1.0$ & Unsuitable & 0 & 0 & 0 & 0 \\
\hline \multirow[t]{2}{*}{$\% \mathrm{E}$} & -10 to +10 & Good & 0 & 4 & 0 & 33.33 \\
\hline & $<-10$ or $>10$ & Poor & 12 & 8 & 100 & 66.67 \\
\hline \multirow[t]{4}{*}{ SAR } & 0 to 10 & Excellent/good & 12 & 12 & 100 & 100 \\
\hline & 10 to 18 & Permissible & 0 & 0 & 0 & 0 \\
\hline & 18 to 26 & Doubtful & 0 & 0 & 0 & 0 \\
\hline & $>26$ & Unsuitable & 0 & 0 & 0 & 0 \\
\hline \multirow[t]{3}{*}{ PI } & $>75$ & Excellent (Class 1) & 0 & 0 & 0 & 0 \\
\hline & 25 to 75 & Good (Class 2) & 0 & 0 & 0 & 0 \\
\hline & $<25$ & Unsuitable (Class 3) & 12 & 12 & 100 & 100 \\
\hline
\end{tabular}


Table 13 Modified Richard quality classification of irrigation water

\begin{tabular}{llcl}
\hline Water class & $\mathrm{EC}\left(\mu \mathrm{scm}^{-1}\right)$ & \multicolumn{1}{l}{ SAR } & Salinity hazard \\
\hline Excellent/good & $<250$ & $0-10$ & Low \\
Permissible & $250-750$ & $10-18$ & Medium \\
Doubtful & $750-2000$ & $18-26$ & High \\
Unsuitable & $2000-3000$ & $26-30$ & Very high \\
Present study & $14.46-52.67$ & $0.01-0.33$ & na \\
\hline
\end{tabular}

Source: Todd 1980

na not available

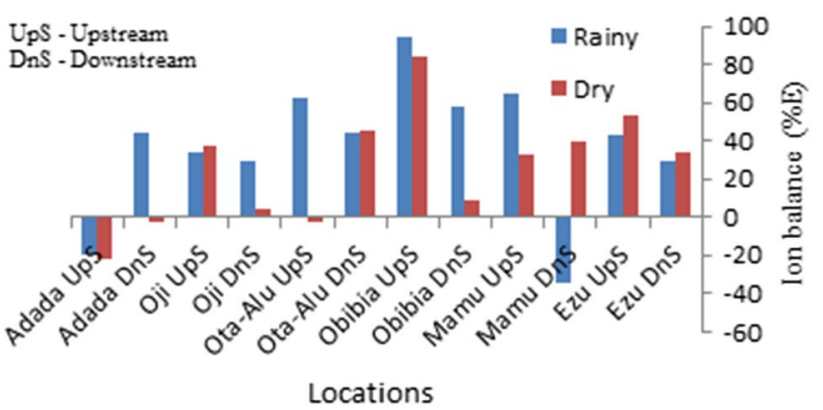

Fig. 9 Ionic balance histogram of River Mamu basin

\section{Water quality for agrarian purposes}

The mineral constituent of any water is the determinant factor to its suitability for irrigation purposes (Nweke et al. 2013), and SAR, SSP, KR, TH, \%E, MAR and \%Na (Tables 10, 12) and the US Salinity Laboratory (USSL) of the Department of Agriculture are some of the quality indices (Wilcox, 1955). The results of the various irrigation water quality criteria are presented in Table 10. The total concentrations of soluble salts in all the sampled water expressed in terms of specific conductance were excellent according to salinity hazard rating for irrigation suitability (Table 13). In general, except for MAR and \%E, other irrigation water quality criteria were within the recommended standards and were classified as excellent (100\%) for both seasons (Table 12). However, MAR revealed otherwise, showcasing that great number of the samples $(83.33 \%$ and $75 \%$ for rainy and dry seasons, respectively) could be unsuitable for irrigation (Table 12).

The unsuitability of water for irrigation as portrayed by MAR could be as a result of ionic imbalance in geochemical such as $\mathrm{Ca}^{2+}$ and $\mathrm{Mg}^{2+}$ emanating from changes in cationic and anionic concentrations due to leaching and anthropogenic activities (Nag and Das, 2014). Freshwater with low TDS is deemed to be good when the ion balance values are between $-10 \%$ and $+10 \%$, and most of the examined samples exceeded these limits (Table 12 and Fig. 9).

Generally, however, from the USSL (1954) diagram, all the water samples are classified as $\mathrm{C} 1-\mathrm{S} 1$ water type which is rated excellently suitable for irrigation based on CGWB (2013) Guidelines (Fig. 10a). The USSL classification is in conformity with Wilcox (1955) classification which is based on sodium percentage and electrical conductivity correlation (Fig. 10b).

With exception of the water from Obibia upstream which has high $\mathrm{Mg}^{2+}$ concentration $(>1000 \mathrm{mg} / \mathrm{l})$ as given in Tables 5 and 6, other locations' samples could be termed satisfactory for livestock drinking water (Table 14). However, the presence of some unsafe substances, particularly

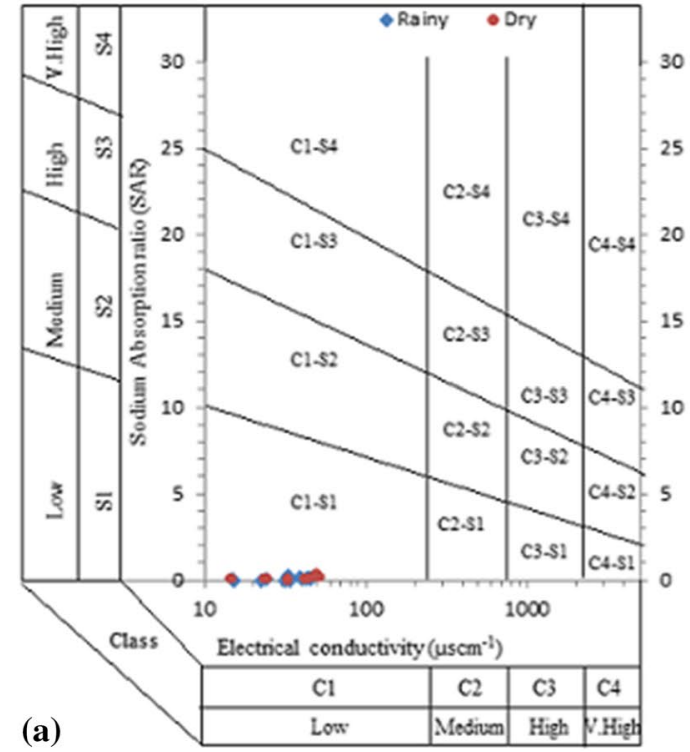

Fig. 10 River Mamu basin's irrigation water classification

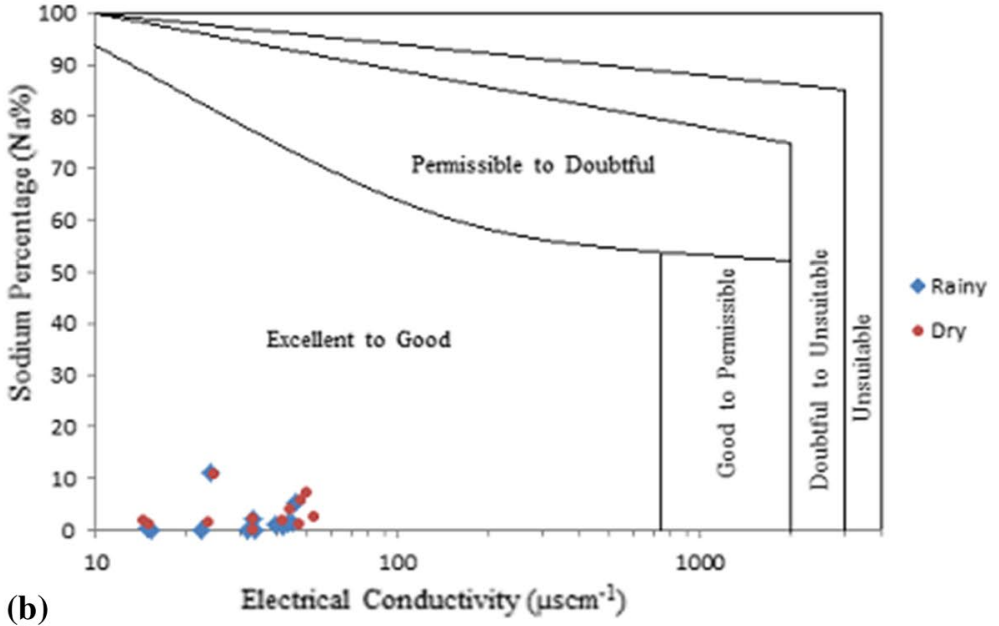


Table 14 Suggested magnesium levels for livestock drinking water

\begin{tabular}{ll}
\hline Livestock & Magnesium $(\mathrm{mg} / \mathrm{l})$ \\
\hline Poultry & $<250$ \\
Swine & $<250$ \\
Horses & 250 \\
Cows (lactating) & 250 \\
Ewes and lambs & 250 \\
Beef cattle & 400 \\
Adult sheep on dry feed & 500 \\
Present study & $19.46-1072.8$ \\
\hline
\end{tabular}

Source: Australian water Resources Council 1969
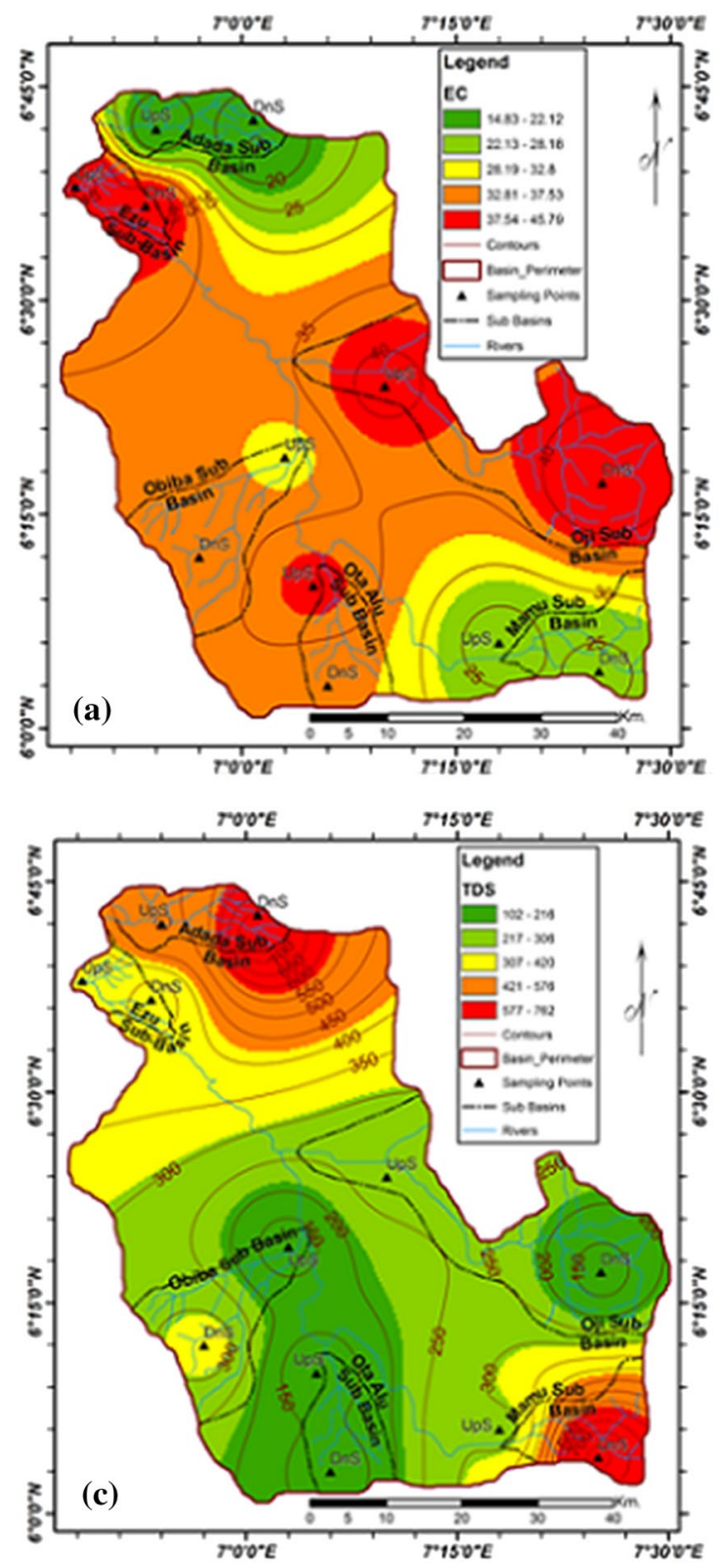

Table 15 Livestock drinking water and irrigation guidelines for toxic substances level

\begin{tabular}{lllll}
\hline Constituents & $\begin{array}{l}\text { Upper limit } \\
(\mathrm{mg} / \mathrm{l}) \\
\text { Livestock }\end{array}$ & \multicolumn{3}{l}{ Present study $(\mathrm{mg} / \mathrm{l})$} \\
\cline { 3 - 5 } & Irrigation & Rainy season & Dry season \\
\hline $\mathrm{Mn}^{2+}$ & 0.005 & 0.2 & $0.01-0.76$ & $0.03-7.50$ \\
$\mathrm{Fe}^{2+}$ & Not needed & 5.0 & $0.01-0.65$ & $0.01-1.20$ \\
$\mathrm{NO}_{3}$ & 100 & - & $0.01-11.6$ & $0.04-2.50$ \\
$\mathrm{Zn}^{2+}$ & 24 & 2.0 & $0.01-16.5$ & $0.01-10.6$ \\
$\mathrm{TDS}$ & 10,000 & 2000 & $102-762$ & $95-800$ \\
$\mathrm{TSS}$ & 10,000 & - & $2.8-520$ & $22-720$ \\
\hline
\end{tabular}

Source: National Academy of Sciences 1972
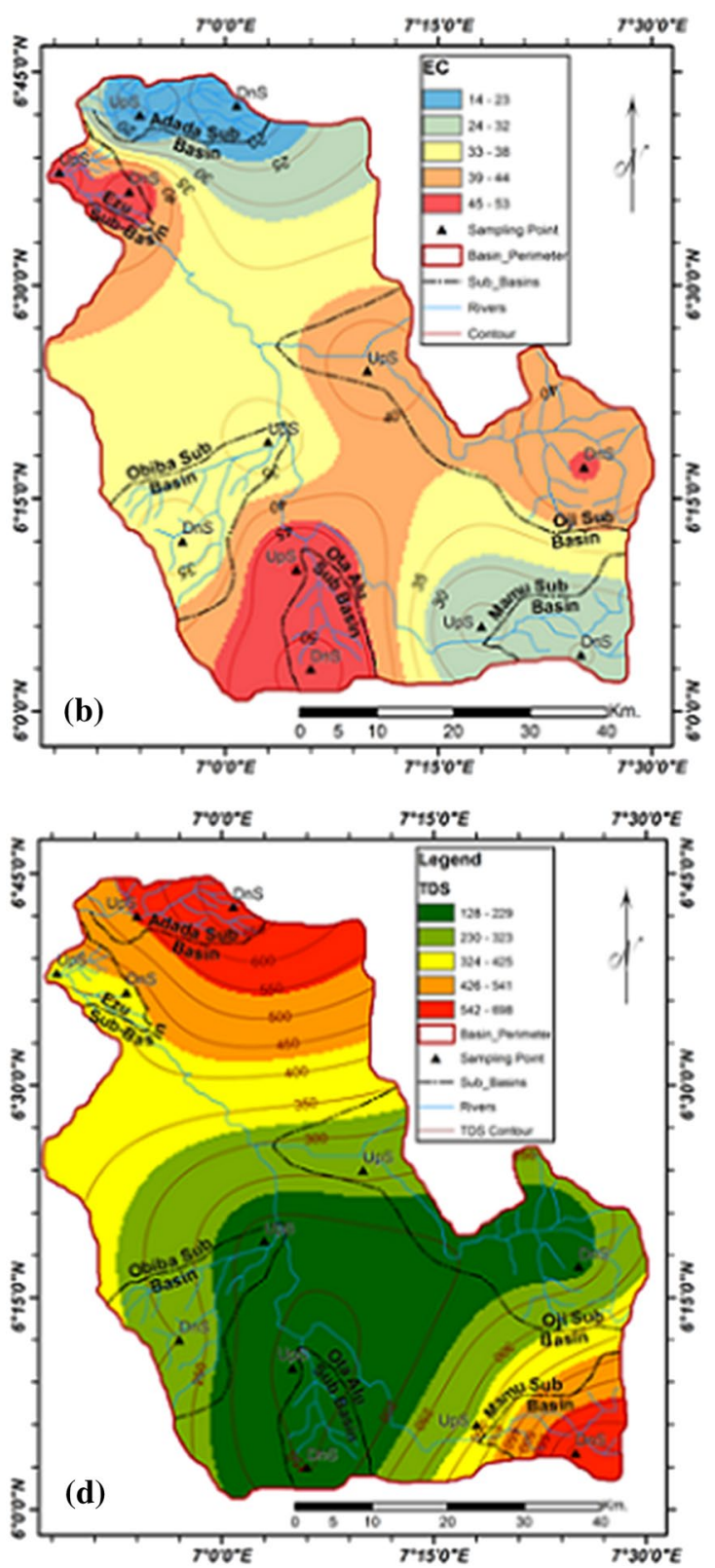

Fig. 11 Spatial distribution of EC and TDS 

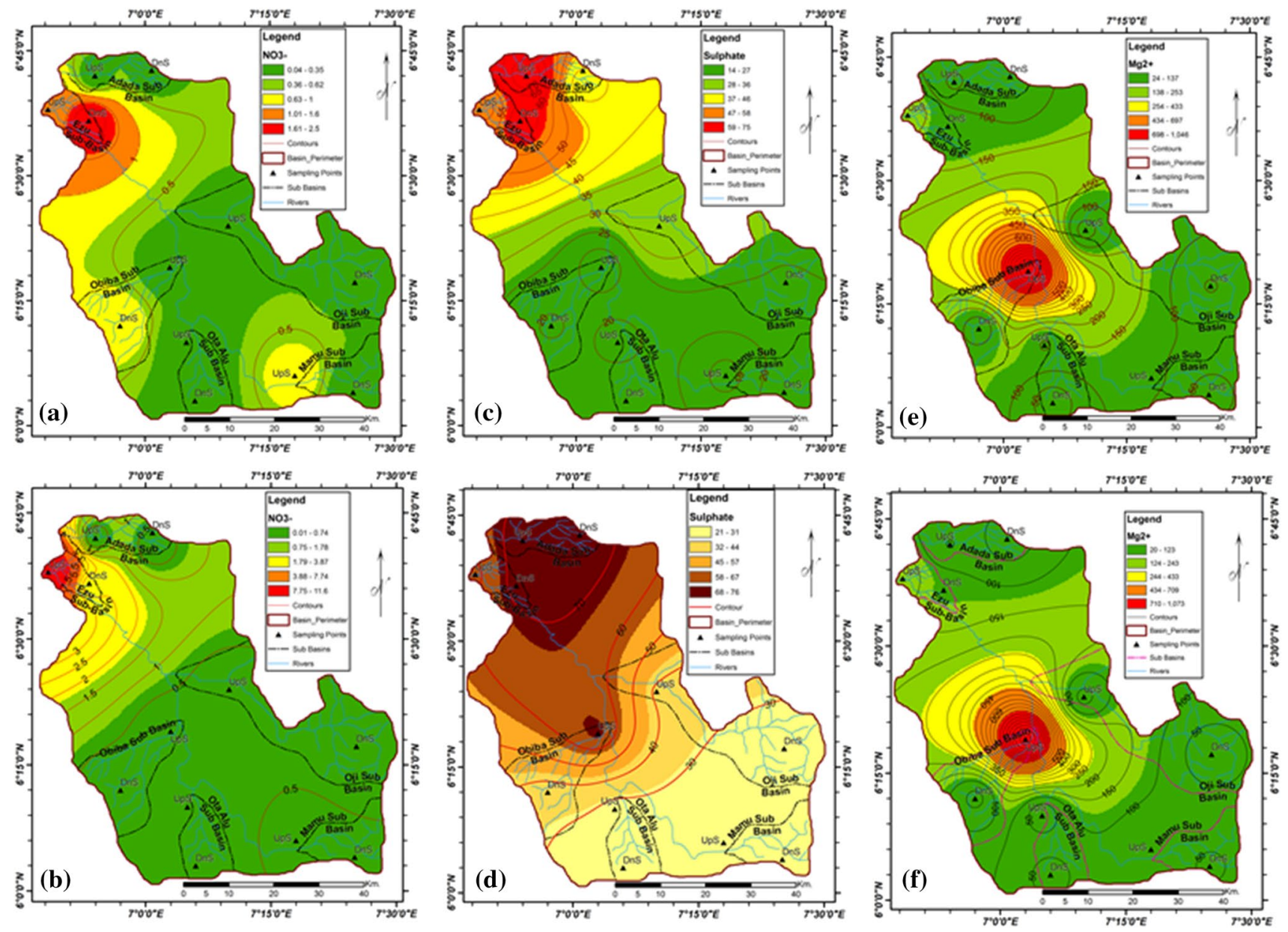

Fig. 12 Spatial distribution of nitrate, sulfate and magnesium

$\mathrm{Mn}^{2+}$ and $\mathrm{Zn}^{2+}$, which are above the recommended standards, could render the water harmful to animals and plants (Table 15).

\section{Spatial variation of ions and rock-water interaction}

Spatial variations of ion in water are a function of oxidation of host rock, change in water chemistry and anthropogenic influences (Okogbue et al. 2012). Figures 11, 12, 13 and 14 show the spatial changes in ion distributions in Mamu River basin.

Electrical conductivity and other hydro-geochemical parameters revealed that water from Mamu main channel and Adada sub-basin in the southeastern and northeastern parts of the basin, respectively, had a better quality than other regions of the basin (Fig. 11a, b) except for anomalous concentration of TDS. While other region (such as Ezu, Obibia, Oji and Ota-Alu) recorded TDS between 95 and $400 \mathrm{mg} / \mathrm{l}$, Mamu main channel and Adada sub-basin recorded as much as $800 \mathrm{mg} / \mathrm{l}$ (Fig. 11c, d). The excess concentration of TDS is explained by the large-scale socioeconomic activities in both regions.

The spatial distribution of nitrate and sulfate showed higher values (between $2.5-11.6 \mathrm{mg} / \mathrm{l}$ and $75-76 \mathrm{mg} / \mathrm{l}$ ) in the northwest, while their concentration $(0.01-0.04 \mathrm{mg} / \mathrm{l}$ and 14-21 mg/l) decreased downward following the direction of the surface water flow (Fig. 12a-d). This suggests that the main source of pollutant occurs outside the basin. Around the central sub-basin of Obibia, excessive concentration of $\mathrm{Mg}^{2+}$ (above $1000 \mathrm{mg} / \mathrm{l}$ ) (Fig. 12e, f) is associated with anthropogenic influence, local geology or mineralization, chemical weathering, dissolution and leaching of rocks.

The $\mathrm{Na}^{+}+\mathrm{K}^{+}$map conformed with the TDS distribution map (Figs. 13a, b, 14c, d). Lower values (between 0.08 and $2.76 \mathrm{mg} / \mathrm{l})$ characterize central parts of the basin covering Obibia sub-basin. Moreover, apart from the existence of high $\mathrm{Mg}^{2+}$ in Obibia sub-basin (12e,f), $\mathrm{Ca}^{2+}+\mathrm{Mg}^{2+}$ map reveals consistency with $\mathrm{Na}^{+}+\mathrm{K}^{+}$and TDS maps in the central part 
of the basin (Fig. 13c,d). Therefore, the central part of the basin is likely to have better water quality, possibly due to lesser interference from upper section of the basins (serving as a channel to the sub-basins downstream) and human activities when compared with areas like Adada, Oji and Mamu sub-basins with known history of massive agricultural and commercial activities.

Hydrochemical ratios and coefficients as shown in Fig. 14 are insightful in determining flow direction and processes controlling the chemical composition of water. Utom et al. (2013) disclosed that chloride concentration increased down the hydraulic gradient and in the direction of flow (Utom et al. 2013). In this study, except for the $\mathrm{NaCl}$ diffuse point
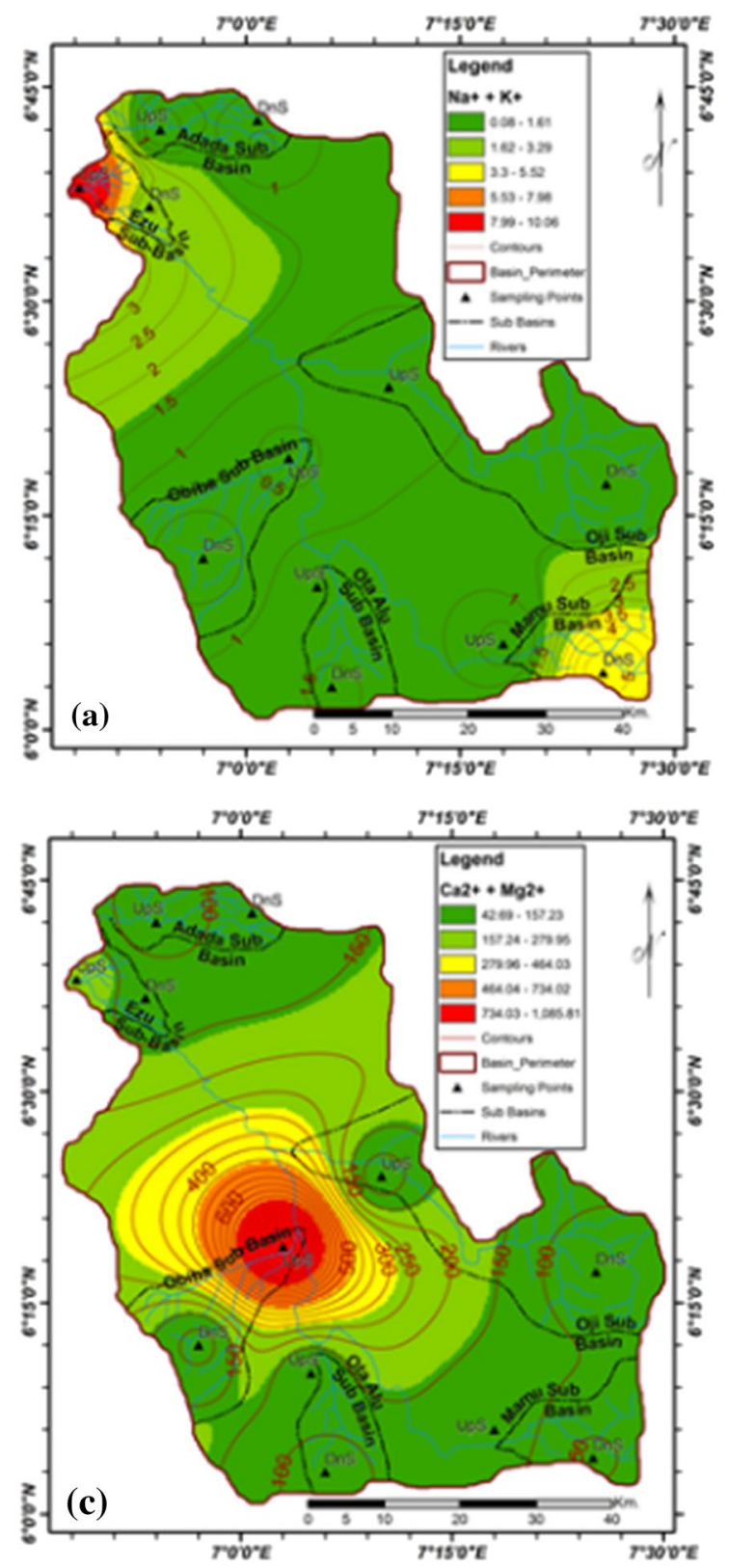

Fig. 13 Spatial distribution of $\mathrm{Na}+\mathrm{K}$ and $\mathrm{Ca}+\mathrm{Mg}$ in the basin water into the basin during the dry season, $\mathrm{Na}^{+} / \mathrm{Cl}^{-}$ratio increases toward the southwest, thus affirming the flow direction to be the southwest (Fig. 14a, b). Supporting this southwest flow direction of Mamu River basin is the increase in ratio of $\mathrm{SO}_{4}{ }^{2-} / \mathrm{Cl}^{-}$toward the southwest (Fig. 14c, d).

Climatic, Fluvio geomorphic and anthropogenic processes a basin supports influence its water use (Nganje et al. 2015) because rock and mineral weathering, evaporation, precipitation and anthropogenic activities are the main sources of ions in basin waters (Singh et al. 2005). In the present study, modified Gibbs (1970) diagrams (Fig. 15) identified rock-water interaction as the most dominant factor influencing surface water chemistry within the Mamu River
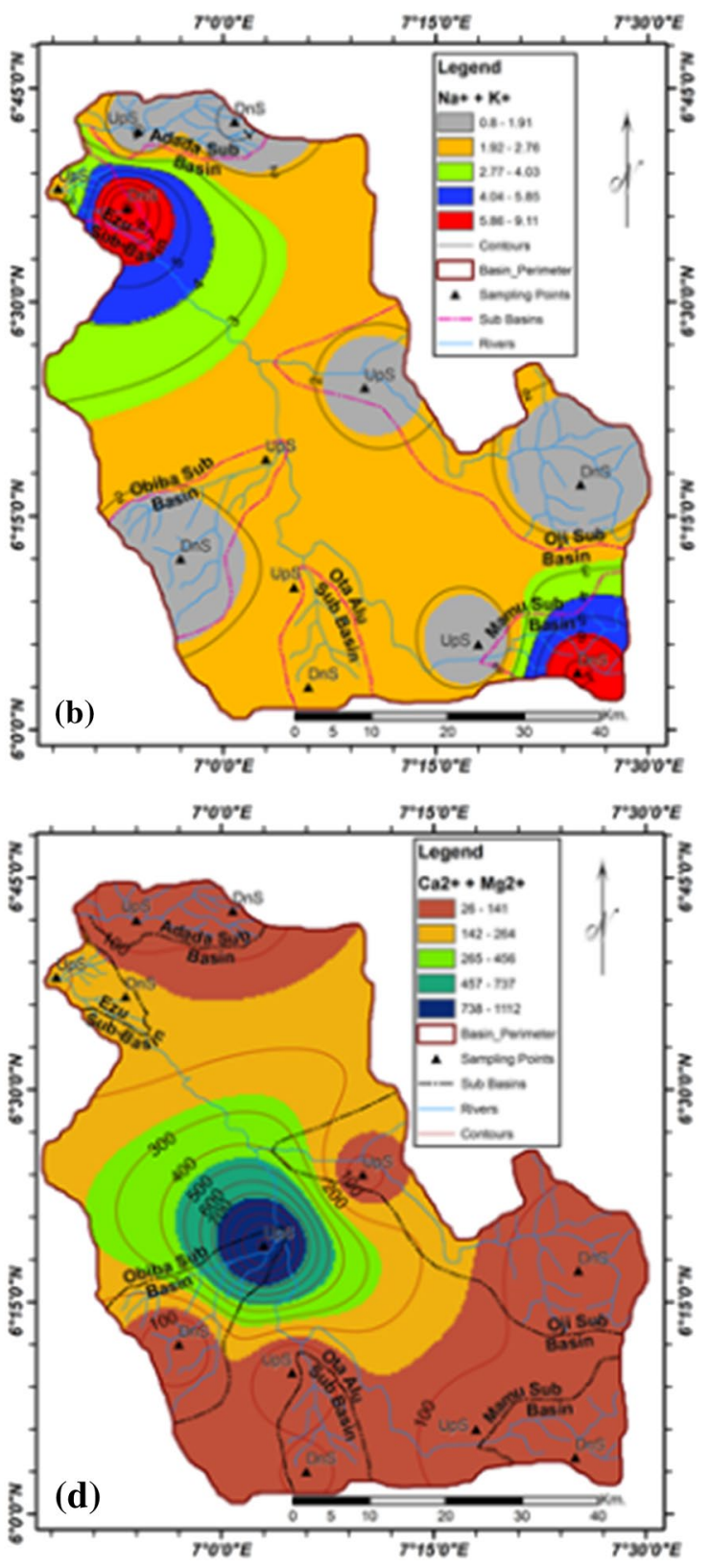
basin (Fig. 15a-c). Therefore, in line with Utom et al. (2013) and Okogbue et al. (2012), weathering, dissolution, displacement reactions and ionic exchange within the basin's rocks are the main causes of changing concentration of major ion in the surface water under study.

However, the weak positive correlation between these parameters and TDS shown in Fig. 16 attests to the notion that rock-water interaction is not the only controlling factor impacting on the water chemistry, thus suggestive of human (anthropogenic) influences.

The Piper (1944) diagrams (Fig. 17) revealed that both seasons are characterized by calcium chloride $\left(\mathrm{CaCl}_{2}\right)$ water type which is associated with permanent water hardness that cannot be softened via boiling but through ion exchange processes. Furthermore, the water samples could be classified as very hard water (Table 12).
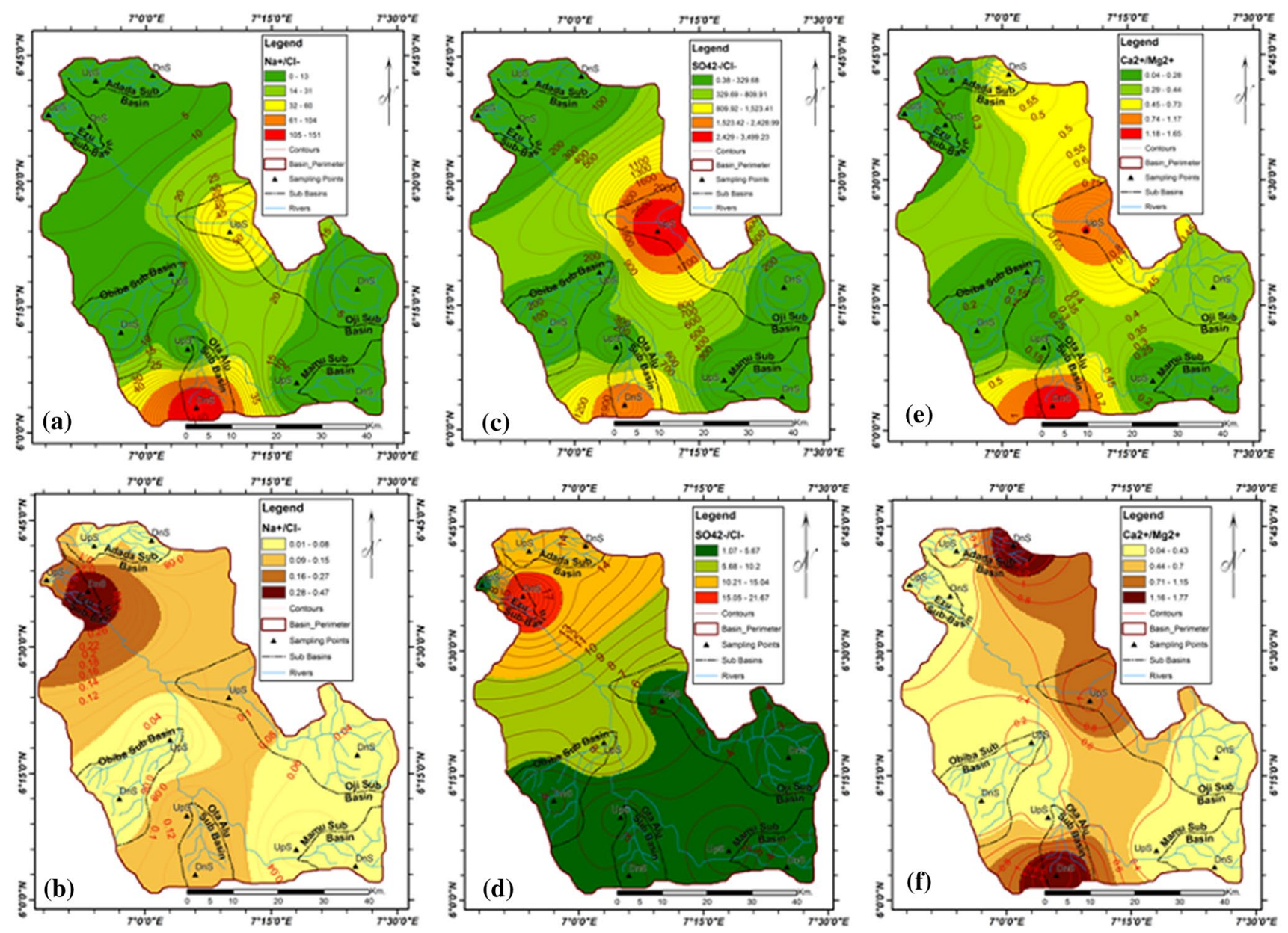

The permanent water hardness could increase along the flow direction as suggested by increase in $\mathrm{Ca}^{2+} / \mathrm{Mg}^{2+}$ toward the southwest along the flow direction (Fig. 14e, f). Moreover, Stiff (1940) diagrams uncovered that hydrochemical characteristics of the water varied from place to place (localities) as revealed by the different shapes of the entire polygon (Figs. 6, 7). It also revealed the dominance of magnesium and sulfate in the water, particularly in the rainy season which is accounted for by dissolution processes.

\section{Conclusion}

The suitability of surface waters from Mamu River basin, southeastern Nigeria, for both domestic and agrarian purposes was the bane of this study. The hydrochemical analyses disclosed that waters from the basin are likely

Fig. 14 Distribution of some geochemical ratios in the water 
to pose some health concerns if ingested without treatment due to higher concentration of one or more constituents (potential toxins) above acceptable limits of relevant standards. Nevertheless, water quality index result revealed that $66.7 \%$ of the water samples are fit for drinking in the rainy season but decline to merely $25 \%$ fit for consumption in the dry season. While the water quality for agricultural purposes is satisfactorily rated excellent and may not pose any form of salinity hazard to irrigation, livestock and poultry farming, the water may require treated before use as a result of ionic imbalance.

Although water in the basin varies from one location to another along the flow direction-from the northwest to the southeast, there was no significant difference in water type and across seasons. Water in the basin was characterized by $\mathrm{CaCl}_{2}$ which is associated with permanent hardness, while $\mathrm{Mg}^{2+}$ and $\mathrm{SO}_{4}{ }^{2-}$ dominated the water, thus suggesting dissolution of host rocks (local geology) as a controlling factor of the water chemistry and variability in water quality. However, there are indicators pointing at anthropogenic activities as influencers of the basin's surface water. Authors therefore recommend robust groundwater development in the basin and good water management policies to reduce dependence on the surface water resources.

\section{Further studies}

Due to the importance of potable water and the Mamu drainage basin to the southeast and Nigeria, there is a need to carry out specific studies in the basin in order to determine the types and sources of pollutants bedeviling the surface drainage. The authors therefore recommend
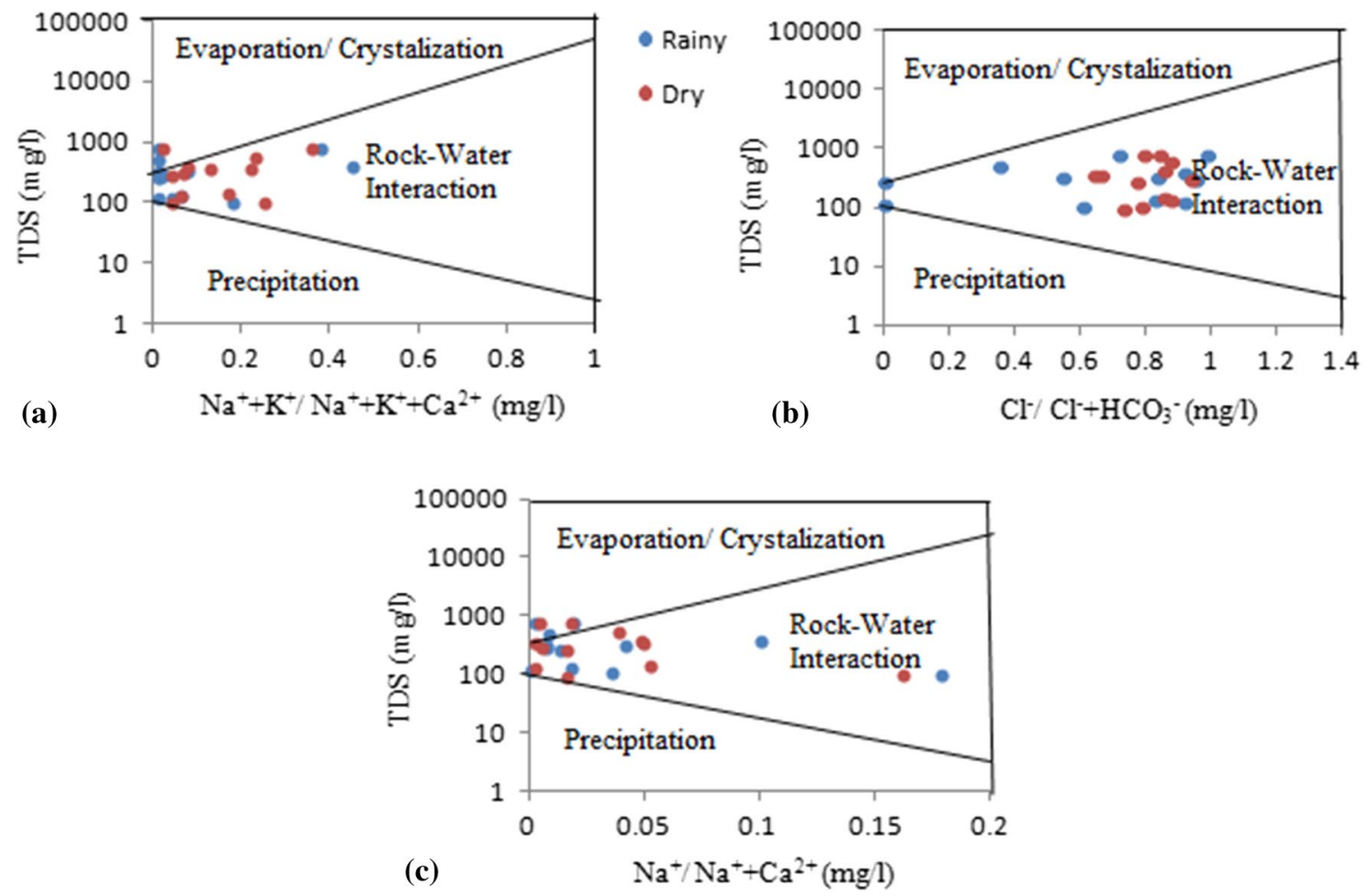

Fig. 15 Modified versions of Gibbs plot 

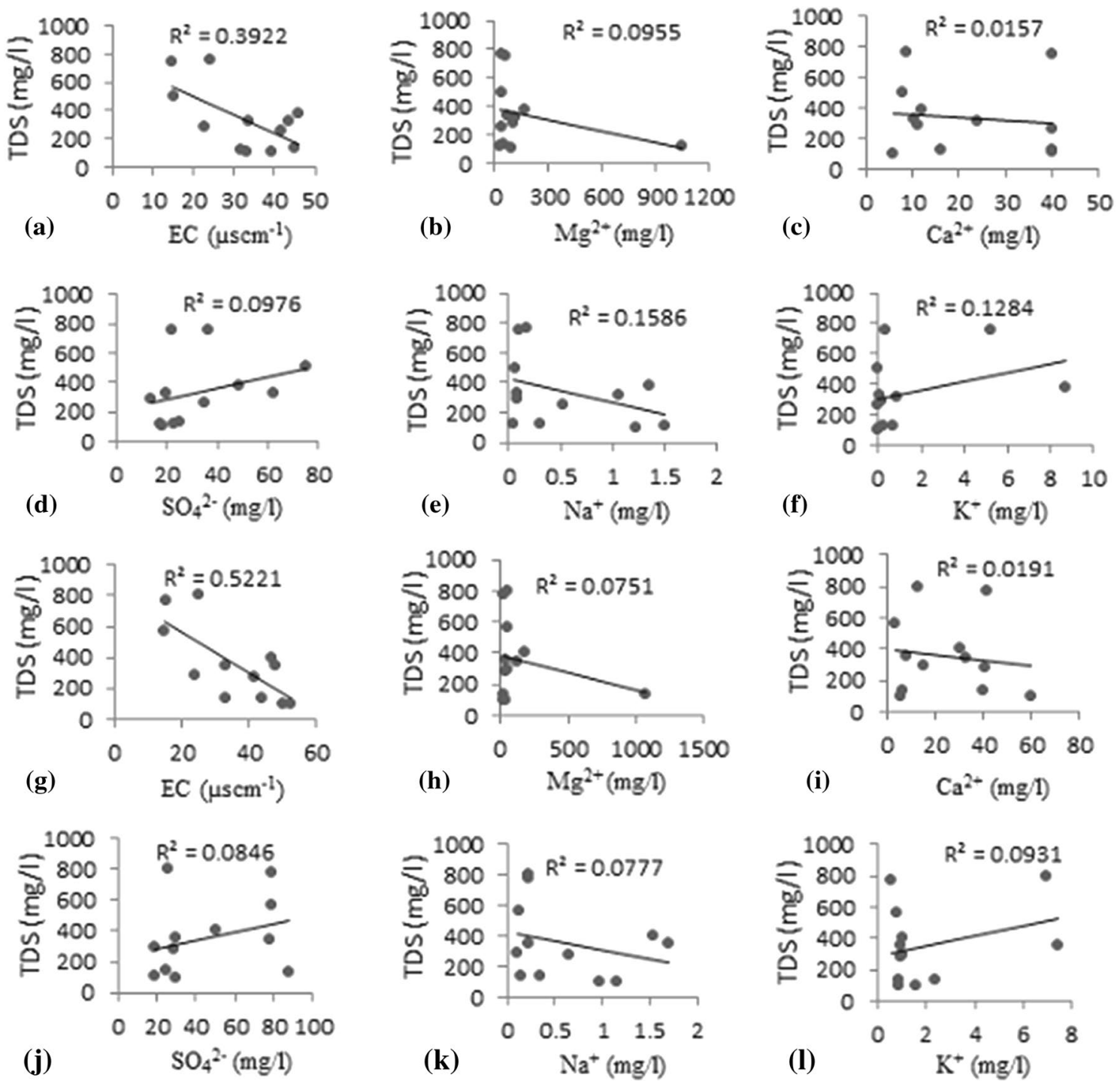

Fig. 16 Correlation between TDS and major hydro-geochemicals

a thorough investigation into the concentration of potential harmful elements (heavy metals and radioactive substances) in the basin waters. It is also essential to perform absolute leachate test in order to determine the pollution sources within the basin. A risk assessment would be a good idea to facilitate proper basin management and policy making, thus providing solutions to the incessant contamination of the rivers and streams in the region. 

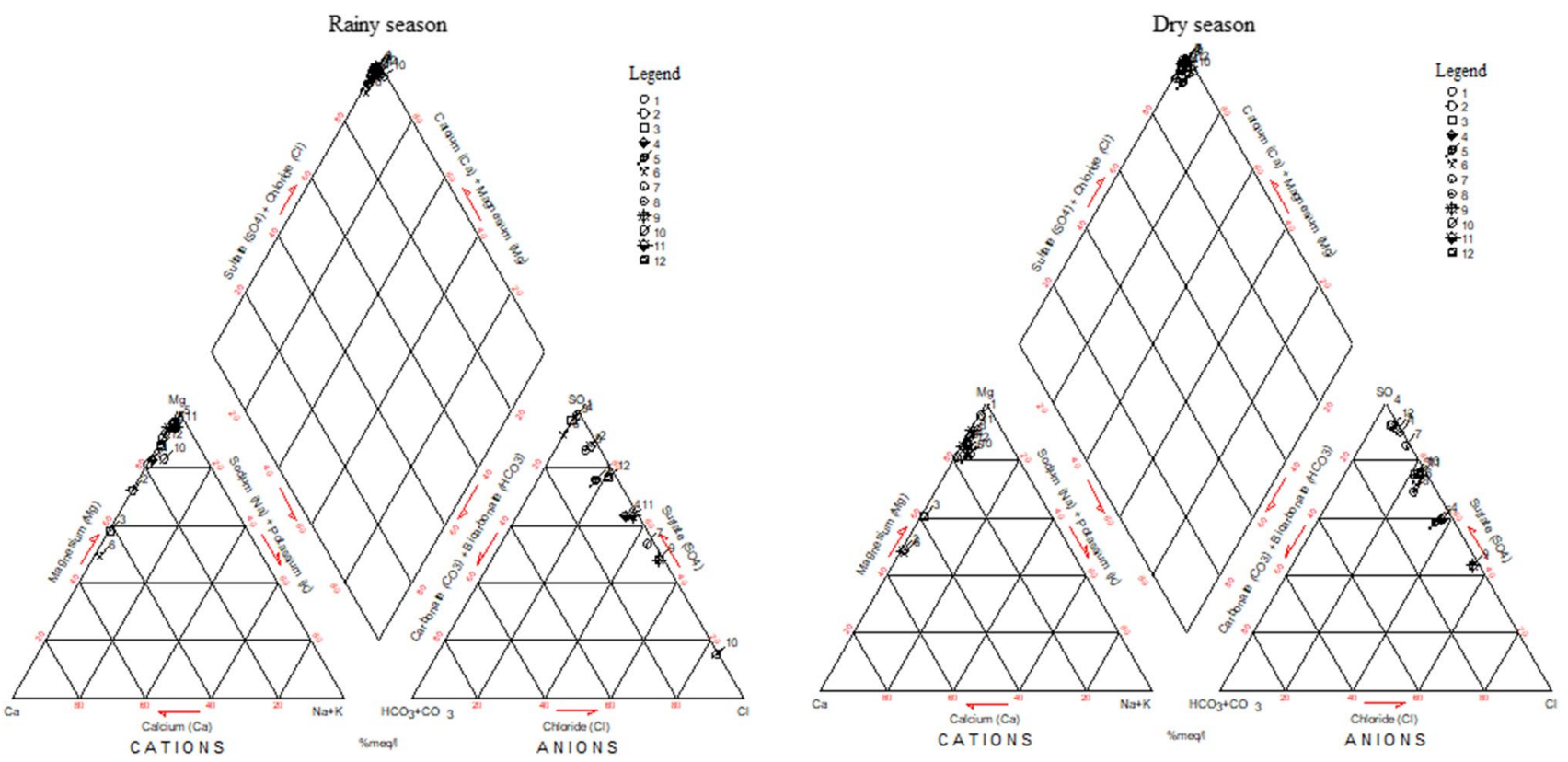

Fig. 17 River Mamu basin water sample plot on the Piper diagram

\section{Compliance with ethical standards}

Conflict of interest The authors declare no conflict of interest.

Open Access This article is licensed under a Creative Commons Attribution 4.0 International License, which permits use, sharing, adaptation, distribution and reproduction in any medium or format, as long as you give appropriate credit to the original author(s) and the source, provide a link to the Creative Commons licence, and indicate if changes were made. The images or other third party material in this article are included in the article's Creative Commons licence, unless indicated otherwise in a credit line to the material. If material is not included in the article's Creative Commons licence and your intended use is not permitted by statutory regulation or exceeds the permitted use, you will need to obtain permission directly from the copyright holder. To view a copy of this licence, visit http://creativecommons.org/licenses/by/4.0/.

\section{References}

Ajon AT, Utsev JT, Nnaji CC (2014) Physicochemical quality of irrigation water in River Katsina-Ala catchment areas of northern Nigeria. Curr World Environ 9(2):301-311

APHA (American Public health Association) (1995) Standard methods for the examination of water and waste water, 19th edn. American Public Health Association, American Water Works Association (AWWA) and Water Environment Federation (WEF). Byrd Prepess Springfield, Washington

AWRS (Australian Water Resources Council) (1969) Quality aspects of farm water supplies. Department of National Development, Canberra

Awachie JBE, Walson EC (1978) Atalla fishery of the lower Niger, Nigeria. CIFA Tech. Pap./Doc. Tech. CPCA, No 5, pp 296-311
Barbieri M, Ricolfi L, Vitale S, Muteto PV, Nigro A, Sappa G (2018) Assessment of groundwater quality in the buffer zone of Limpopo National Park, Gaza Province, Southern Mozambique. Environmental Science and Pollution Research. https://doi. org/10.1007/s 11356-018-3474-0

Boah DK, Twum SB, Pelig-Ba KB (2015) Mathematical computation of water quality index of Vea dam in upper east region of Ghana. Environ Sci 3(1):11-16. https://doi.org/10.12988/es.2015.4116

CGWB (2013) Ground water year book: India 2012-13. Central Ground Water Board, Ministry of Water Resources, Faridabad

Diagi BE (2018) Analysis of rainfall trend and variability in Ebonyi state, South Eastern Nigeria. Environ Earth Sci Res J 5(3):53-57. https://doi.org/10.18280/eesrj.050301

Dinka MO, Loiskandl W, Ndambuki JM (2015) Hydrochemical characterization of various surface water and groundwater resources available in Matahara areas, Fantalle Woreda of Oromiya region. J Hydrol Reg Stud 3:444-456

Doneen LD (1964) Notes on water quality in agriculture. Water Science and Engineering, Paper 4001, Department of Water Sciences and Engineering, University of California, Davis

Eneh OC (2007) Improving the access to potable water in Nigeria. Afr J Sci 8(2): 1962-1971

Etim NAA, Udoh EJ (2013) The determinants of rural poverty in Nigeria. Int J Agric Manag Dev 3(2):141-151

Evans CD, Monteith DT, Cooper DM (2005) Long-term increases in surface water dissolved organic carbon: observations, possible causes and environmental impacts. Environ Pollut 137(1):55-71

Eyankware MO, Okoeguale BO, Ulakpa ROE (2017) Assessment of physico-chemical properties of surface water, of Oji town and its adjoining areas, Anambra basin, se. Nigeria for irrigation purpose. Galore Int J Appl Sci Human 1:29-43

FAO (2005) Irrigation in Africa in figures-QUaStat Survey: Nigeria. Food and Agricultural Organisation, Rome, pp 433-446

Fetter CW (2000) Applied hydrogeology: Upper Saddle River, 4th edn. Prentice Hall Inc., New Jersey

FGN (2004) National water policy. Federal Government of Nigeria, Abuja, p 28 
Freeze RA, Cherry JA (1979) Groundwater. Prentice Hall, Englewood Cliffs

Gibbs RJ (1970) Mechanisms controlling world's water chemistry. Science 170:1088-1090

Gideon YB, Fatoye FB, Omada JI (2013) Quality assessment of physico-chemical characteristics of Okura River, Kogi State, Nigeria. Int J Sci Technol 2(12):981-899

Ishaku HT, Majid RM, Ajayi AP, Haruna A (2011) Water supply dilemma in Nigerian rural communities: looking towards the sky for an answer. J Water Resour Prot 3:598-606. https://doi. org/10.4236/jwarp.2011.38069

Kelly WP (1963) Use of saline irrigation water. Soil Sci 95(4):355-439

Khodapanah L, Sulaiman WNA, Khodapanah N (2009) Groundwater quality assessment for different purposes in Eshtehard district, Tehran. Iran Eur J Sci Res 36(4):543-553

Kogbe CA (1981) Attempt to correlate the stratigraphic sequence in the middle Benue basin with those of the Anambra and upper Benue basins. Earth Evol Sci 1(2):139-148

Laze P, Rizani S, Alban I (2016) Assessment of irrigation water quality of Dukagjin basin in Kosovo. J Int Sci Publ 4:544-551

Lohdip YN, Gongden JJ (2013) Nigerian water bodies in jeopardy: the need for sustainable management and security. WIT Trans Ecol Environ 17:11-22. https://doi.org/10.2495/WRM130021

Monanu S, Inyang F (1975) Climatic regimes. In: Ofomata GEK (ed) Nigeria in Maps. Ethiope Publication House, Benin, pp 27-29

Nag SK, Das S (2014) Quality assessment of groundwater with special emphasis on irrigation and domestic suitability in Suri I \& II Blocks, Birbhum District, West Bengal. India Am J Water Resour 2(4):81-98

National Academy of Sciences and Engineering (1972) Water quality criteria. United States Environmental Protection Agency, Washington DC, Report No. EPA-R373-033, p 604

Nfor BN (2003) Sedimentary facies and the diagnostic characteristics for the Campanian-Eocene Anambra Basin. Unpublished Ph.D. thesis submitted to the Department of Geological Sciences, Nnamdi Azikiwe University, Awka, p 236

Nganje TN, Hursthouse AS, Edet A, Stirling D, Adamu CI (2015) Hydrochemistry of surface water and groundwater in the shale 3 bedrock, Cross River Basin and Niger Delta Region, Nigeria. Appl Water Sci https://doi.org/10.1007/s13201-015-0308-9

Nwankwor GI, Egboka BC, Orajaka IP (1988) Groundwater occurrence and flow pattern in the Enugu coal-mine area, Anambra State, Nigeria. Hydrol Sci J 33:465-482

Nweke OM, Aghamelu OP, Obasi IA (2013) Hydrogeochemical analysis and quality evaluation of groundwater from Onicha-Uburu, Southeastern Nigeria for irrigation purposes. Afr J Environ Sci Technol 7(5):222-228. https://doi.org/10.5897/AJEST12.095

Nzeadibe TC, Ajaero CK (2011) Development impact of advocacy initiatives in solid waste management in Nigeria. Environ Dev Sustain 13(1):163-177

Odetola T, Etumnu C (2013) Contribution of agriculture to economic growth in Nigeria. In: Proceeding: the 18th Annual Conference of the African Econometric Society (AES), Accra, Ghana 22nd and 23rd July 2013, pp 1-28

Okogbue CO, Omonona OV, Aghamelu OP (2012) Qualitative assessment of groundwater from Egbe-Mopa basement complex area, northcentral Nigeria. Environ Earth Sci 67:1069-1083. https:// doi.org/10.1007/s12665-012-1552-z

Paliwal KV (1972) Irrigation with saline water, Monogram No. 2 (New Series). New Delhi, IARI, p 198

Pavelic P, giordano M, Keraita B, Ramesh V, Rao T (2012) Groundwater availability and use in Sub-Saharan Africa: a review of 15 countries. Colombo, Sri Lanka: International Water Management Institute (IWMI). https://doi.org/10.5337/2012.213
Phil-Eze PO (2001) Biodiversity and environmental problems in Nigeria. In: Ofomata GEK, Phil-Eze PO (eds) Geographical perspectives on environmental problems and management in Nigeria. Jamoe Publishers, Enugu, pp 33-52

Piper AM (1944) A graphical procedure in geochemical investigation of water analysis. Trans Am Geophys Union 25:914-923

Population Reference Bureau (prB) (2000) World population data sheet, 2000. [wall chart]. Washington, D.C.

Ragunath HM (1987) Groundwater. Wiley Eastern Ltd, New Delhi, pp 563-569

Shah SM, Mistry NJ (2013) Groundwater quality assessment for irrigation use in Vadodara district, Gujarat, India. Int Sch Sci Res Innov 7(7):719-724

Shell BP (1957) Geological map. Sheet Enugu 64(1):250000 (Nigeria)

Shodhganga (2019) Chapter 7: Water quality index. Retrieved 2 February 2019 . https://shodhganga.inflibnet.ac.in/bitstream/10603 /10079/12/12_chapter\%25207.pdf

Singh AK, Mondal GC, Singh PK, Singh S, Singh TB, Tewary BK (2005) Hydrochemistry of reservoirs of Damodar River basin, India: weathering processes and water quality assessment. Environ Geol 48:1014-1028

SON (Standard Organization of Nigeria) (2007) Nigerian Industrial Standard: Nigerian standard for drinking water quality. Abuja, Standard Organization of Nigeria Wuse, p 30

Stiff HA Jr (1940) Interpretation of chemical water analysis by means of patterns. J Petrol Technol 3:15-16

Todd KD (1980) Groundwater hydrology. Wiley, New York, p 535

UNDESA (2012) Water quality. International decade for action: water for life 2005-2015. www.un.org/waterforlifedecade/quality.

UNDP (2013) Inequalities in Human Development in the 21st Century: Briefing note for countries on the 2019 Human Development Report, Nigeria. Human Development Report 2019. https://hdr.undp.org/en/ data. Accessed 25 Apr 2019

UNESCO/WHO/UNEP (1996) Water quality assessment—a guide to use of biota, sediments, and water in environmental monitoring, 2nd edn. University Press, Cambridge, p 609

UNEP (United Nations Environment Programme) (2008) Vital water graphics-an overview of the state of the world's fresh and marine waters, 2nd edn. UNEP, Nairobi

UNICEF and WHO (2009) Progress on drinking water and sanitation. A millennium development goal (MDG) assessment on progress for children: a report Card. www.childinfo.org/water.html. Accessed 7th Mar 2009

Urbaniak M, Pietrzak S (2011) Dissolvable organic carbon in groundwater as an indicator of its contamination as a result of many years of on-ground storage of manure. Pol J Agron 4:33-37

USSL (United States Salinity Laboratory) (1954) Diagnosis and improvement of saline and alkali soils. Agricultural handbook vol 60. US Government Printing Office, $p 160$

Utom AU, Odoh BI, Egboka BCE (2013) Assessment of hydrogeochemical characteristics of groundwater quality in the vicinity of Okpara coal and Obwetti fireclay mines, near Enugu town, Nigeria. Appl Water Sci 3:271-28. https://doi.org/10.1007/s13201-013-0080-7

WHO (World Health Organization) (2007) Guidelines for drinking-water quality: incorporating first and second addenda, Recommendations, 3rd edn, vol 1. WHO Press

Wilcox LV (1955) Classification and use of irrigation waters. United State Department of Agriculture (USDA), Circular 969. Washington

Publisher's Note Springer Nature remains neutral with regard to jurisdictional claims in published maps and institutional affiliations. 